\title{
Обзор исследовательской литературы
}

\section{по теме священства в творениях святителя Григория Богослова*}

\author{
Н. К. Антонов \\ Православный Свято-Тихоновский гуманитарный университет, \\ Российская Федерация, 127051, Москва, Лихов пер., 6
}

Для цитирования: Антонов Н. К. Обзор исследовательской литературы по теме священства в творениях святителя Григория Богослова // Вопросы теологии. 2021. Т.3, № 2. C. 177-208. https://doi.org/10.21638/spbu28.2021.204

В статье рассматривается традиция исследований темы священства в наследии свт. Григория Богослова с XIX в. по 2020 г. В обзор включены общие монографии, посвященные как становлению епископата в поздней Античности, так и специально наследию Назианзина, диссертации, публикации в периодических изданиях, словарях и энциклопедиях по указанной теме, а также по широкому кругу смежных тем, ключевые издания и переводы «Апологии» центрального текста свт. Григория о священстве - на английском, русском, немецком, французском и итальянском языках. Предложена следующая периодизация историографии: ранний период (XIX - середина XXв.), богословские исследования «Апологии» 1950-1970-х годов, исследования и издания Ж. Бернарди, новая волна исследований 1990-х годов, ее развитие в XXI в. В последнем периоде выделены три основные тенденции и тексты Богослова о священстве рассматриваются в контексте развития в поздней Античности образа монаха-епископа, платонической политической философии, его основных богословских концептов. Показано значение исследований других

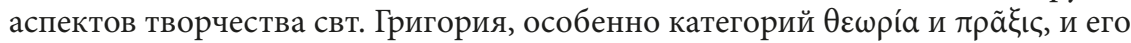
автобиографических текстов. В качестве наиболее перспективных предложены две линии дальнейших исследований: интертекстуальный анализ «Апологии» и интегральный анализ всего наследия свт. Григория через призму темы священства.

Ключевые слова: свт. Григорий Богослов, священство, историография, поздняя Античность, автобиография, богословие.

\section{Введение}

Исследования наследия свт. Григория Богослова имеют долгую традицию, однако один из значимых аспектов его творчества, а именно тема

* Исследование выполнено при финансовой поддержке РФФИ в рамках научного проекта № 20-311-90020.

(C) Санкт-Петербургский государственный университет, 2021

(c) Общецерковная аспирантура и докторантура им. святых равноапостольных Кирилла и Мефодия, 2021 
священства ${ }^{1}$, оставаясь в тени в XIX-XX вв., стал предметом детального анализа лишь в последние десятилетия. Важными при обращении к историографии по данному вопросу являются сам факт вхождения раздела об учении свт. Григория о священстве во все общие работы о нем в конце 1990-х годов и полное отсутствие таковых до этого времени. Кроме того, стабильный рост количества исследований по данной и смежным темам вплоть до нынешнего момента свидетельствует о том, что эти исследования пока не исчерпали себя. Представляется, что в нынешней ситуации необходимо рассмотрение историографии этого вопроса: лишь реконструировав оптику, в рамках которой произошел рост интереса к данной теме в последние десятилетия, а также предшествовавшие этому проекты, не получившие развития, можно будет обобщить опыт и определить дальнейшие траектории исследования.

Обзор выстроен в основном по хронологическому принципу, однако иногда мы отступали от него ради выделения в историографии основных концептуальных течений. Для этого в числе прочего ставился вопрос о том, как исследования других аспектов творчества Назианзина влияли на изучение темы священства.

Сначала мы рассмотрим исследования, выполненные в XIX-XX вв. до критического издания «Апологии» ${ }^{2}$ свт. Григория в 1978 г., сыгравшего значительную роль в нашем сюжете.

\section{1. Ранний период: XIX - середина XX века}

В указанный период тема священства, как требующая отельного внимания и анализа, крайне редко выделялась в творчестве Назианзина ${ }^{3}$. Тем не менее остановимся на нескольких значимых исследованиях.

${ }^{1}$ Говоря о «священстве» и «священнике», мы следуем использованию свт. Григорием термина ієрєú, т. е. имеем в виду любого клирика, облеченного властью совершать таинства, без учета разделения на пресвитерский или епископский сан. Несмотря на то что свт. Григорий чаще говорит о епископах или к ним обращается, «Апология» (3-е Слово, Oratio 2), самый значимый его текст о священстве, написана им по поводу рукоположения в сан пресвитера, что отдельно подчеркивается в Or. 2.5. Из этого отрывка видно, что обе должности рассматриваются им в единой логике.

${ }^{2}$ В западной традиции - Oratio 2, в серии Творений Святых Отцов - 3-е Слово «Григорий Богослов оправдывает удаление свое в Понт после рукоположения в пресвитеры и возвращение оттуда, а также учит, как важен сан священства и каков должен быть епископ». Все названия Слова являются позднейшими добавлениями (см. сн. 1 в: Gregoire de Nazianze. Discourse 1-3 / ed. by J.Bernardi. Paris: Les Éditions du Cerf, 1978. P. 84-85). Сложности в нумерации и сосуществование разных названий (Apologia de fuga sua, On his flight to Pontus и т. п.) побуждают нас в данной работе всегда называть этот текст «Апология».

${ }^{3}$ См. раздел «Требования Григория к богословам вообще и особенно к практическому духовенству» в первой общей монографии о свт. Григории в XIX в.: Ullmann C. Gregor von Nazianz, der Theologe. Darmstadt: Verlag von Carl Wilhelm Leske, 1825. S. 509-533. — В анализе Ульманна можно выделить две ключевые линии: 1) соединение темы священства с темой богословствования вообще, что обусловлено влиянием концепции «практи- 
В предисловии к публикации «Апологии» в Patrologia Graeca ${ }^{4}$, несмотря на его краткость, отражен весьма значимый момент реакции на предшествующую, условно «донаучную», эпоху. Поскольку более ранние исследователи полагали, что слово ієрєи́ৎ обозначало в данном контексте исключительно епископский сан, авторы уточняют: свт. Григорий говорил о пастырях вообще, поскольку Слово было произнесено им по поводу его рукоположения во пресвитера. Вопрос о корректном понимании этого ключевого термина ставит более широкий вопрос о понимании Слова в средневековой традиции, который требует отдельного исследования. Представляется, что сужение лексического поля слов sacerdotium /

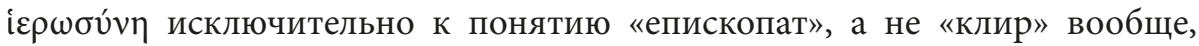
неадекватно реалиям поздней Античности. По-видимому, отраженный, в частности, в этом изменении семантики условный переход от поздней Античности к Средневековью и привел к упрощенному прочтению «Апологии» свт. Григория как исключительно автобиографического текста.

Русские дореволюционные исследования по историческим причинам не вошли в общеевропейский дискурс. Однако эта тема разрабатывалась в них достаточно успешно 5 . Например, П. Борисовский в двух статьях конца XIX в. ${ }^{6}$ соединяет тему священства с рассмотрением этического учения свт. Григория. Он видит неразрывную связь между представлениями

ческого богословия» Шлейермахера; 2) подчеркивание практических добродетелей в описании священника, что вписывается в пиетический бэкграунд автора. Монография была переиздана в 1867 г., после чего в 1869 г. в «Трудах Киевской духовной академии» вышел «перевод» этого фрагмента (К. С. Святой Григорий Назианзин как обличитель недостойных пастырей // Труды Киевской духовной академии. 1869. № 4. С. 3-13). В «переводе» ряд моментов опущен, несколько фрагментов текста добавлены, евангелическое «практическое духовенство» по тексту последовательно заменено концептом «пастырь», что отражает важные процессы изменения понимания образа священника в России конца XIX в. В то время выполнялся новый перевод «Апологии» вместе с «Шестью словами» Златоуста на немецкий язык; об этой линии сравнения двух классических текстов мы скажем ниже. Также отметим статью: Menn. Zur Pastoraltheologie Gregors von Nazianz // International Theological Review. 1904. Vol. 12. P. 427-440. Несмотря на ее общий характер (по сути, это пересказ «Апологии» с комментариями), сам факт ее появления, очевидно, повлиял на последующие работы за счет выделения темы священства как самостоятельного раздела в исследованиях творчества Назианзина, доказательством чему служат ссылки на эту статью, встречающиеся во многих позднейших публикациях.

${ }^{4}$ Gregorius Nazianzenus. Opera quae existant omnia / ed. by J.-P. Migne. D’Amboise, 1862 (Patrologia Graeca. Vol.35). P. 401-406.

${ }^{5}$ Развитие русской богословской науки в XX в. по независящим от Церкви причинам было остановлено, чем объясняется достаточно слабый уровень работ: Шевчук $M$., свящ. Учения святителей Григория Богослова и Иоанна Златоуста о высоте пастырского служения: дис. ... канд. богосл. наук. Загорск: Московская духовная академия, 1965; Сергеенко A., nрот. Св. Григорий Богослов о пастырском служении // Журнал Московской патриархии. 1956. Т. 12. С. 52-56.

${ }^{6}$ Борисовский П.: 1) Догматические основы христианской морали по творениям святого Григория Богослова // Вера и разум. 1894. № 7. С. 443-457; № 8. С. 509-525; 2) Мысли святого Григория Богослова о христианской жизни уединенно-созерцательной и общественно-деятельной // Там же. 1898. № 6. С. 349-374; № 8. С. 491-520. 
свт. Григория о созерцательном и практическом путях и учением о священстве, в чем опережает большинство западноевропейских исследователей более чем на полвека. Отдельно упомянем монографию «Св. Григорий Богослов Назианзин как пастырь и учитель пастырства» ${ }^{7}$, полностью посвященную нашей теме. Первая ее часть, биографическая, как и другие отечественные работы ${ }^{8}$, сконцентрирована на личности свт. Григория как пастыря. Этот ракурс отличает русскую традицию от западной, которая большее внимание уделяет богословской деятельности святителя9. Вторая часть излагает собственно учение о пастырстве. Она ценна проработанностью источников, поскольку включает в себя подробный анализ всех творений святителя. Предложенная в ней система - общие основания пастырства, становление пастыря, пастырское действие, священник в обществе - представляется разумной, однако, как всякая систематизация, имеет и (неизбежный) недостаток в отделении избранных для анализа фрагментов от их исходного контекста.

Нельзя обойти вниманием подробный анализ категории $\pi \alpha \iota \delta \alpha \gamma \omega \gamma \dot{\alpha} \alpha$ в трудах свт. Григория, осуществленный Ф. Портманном ${ }^{10}$. Его исследование предлагает целостный взгляд на творчество святителя, рассматриваемое через указанную категорию, причем именно в этом контексте осмысляется и интересующая нас тема. В ходе анализа «Апологии» автор приходит к заключению, что главная задача священника, по мысли свт. Григория, не управлять паствой, но воспитывать ее, т. е. вести людей к обожению. Кроме общего анализа ключевых категорий, автор выделяет схожие черты в «Государстве» Платона и сочинении святителя, что позволяет рассматривать последнее как самостоятельное высказывание в платоническом контексте, формирующее собственную христианскую систему власти в Церкви.

${ }^{7}$ Григорий (Васильев), архим. Св. Григорий Богослов Назианзин как пастырь и учитель пастырства. Сергиев Посад: Типография Свято-Троицкой Сергиевой лавры, 1916; Садов Ф. Пастырские наставления св. Григория Богослова // Вера и разум. 1888. № 1 (2). C. 674-703.

${ }^{8}$ См., напр.: [Аноним.] Посвящение св. Григория Богослова во пресвитера // Кишиневские епархиальные ведомости. 1894. № 2. С. 31-42; Агапит, архим. Жизнь св. Григория Богослова, архиеп. Константинопольскаго, и его пастырская деятельность. СПб., 1869; Попов И.В. Григорий Богослов // Православная богословская энциклопедия. 1903. Т. 4. С.615-626; [Троицкий И.Е.] Последние годы жизни св. Григория Богослова // Христианское чтение 1863. Ч.2, № 6. С. 147-193.

${ }^{9}$ Иными словами, если западные исследования воспринимают деятельность свт. Григория скорее в контексте общей интеллектуальной истории Церкви, то для российской оптики расстояние в полторы тысячи лет не мешает видеть свт. Григория как актуальный пример пастырства, а «отношения сил» того времени (епископ - паства - еретики - соборы - власти) воспринимаются как когерентные для ситуации автора в силу их церковности. Однако это общее утверждение требует дополнительного рассмотрения, которое было бы интересно при анализе исторических установок исследователей XIX начала XX в.

${ }^{10}$ Portmann F.X. Die göttliche Paidagogia bei Gregor von Nazianz: eine dogmengeschichtliche Studie. Ottilien: St. Ottilien Eos Verlag, 1954. 


\section{2. Богословские исследования «Апологии»}

В 1950-1960-е годы появляется ряд католических исследований по богословию священства в «Апологии».

Вероятно, интерес к этой теме связан с подготовкой и проведением Второго Ватиканского собора. Соответственно, попытка обоснования функций священства через святоотеческую традицию может восприниматься как критическое высказывание против либерального, в смысле пересмотра позиции клира в Церкви, подхода.

Полемический подход статей обусловливает рассмотрение темы священства вне исторического и тем более эллинистического интеллектуального контекста, что не позволяет исследователям выйти на более глубокий уровень анализа ${ }^{11}$. Тем не менее четыре рассмотренные статьи предлагают весьма подробный разбор «Апологии». Первая статья вписывает священство в общие экклезиологические представления Назианзина и рассматривает священника в четырех ракурсах: «отец», «пастырь (врач)», «учитель», «посредник» ${ }^{12}$. Вторая, рассматривая бегство и возвращение свт. Григория, показывает, что физическое удаление свт. Григорий воспринимал не как снятие сана, но как временное уединение перед окончательным примирением с новым статусом ${ }^{13}$. Третья выделяет в тексте Богослова гомилетические предписания ${ }^{14}$, а четвертая, того же автора, описывает призвание ко священству, место священника в Церкви, его область действия, а также рассматривает специфику различных чинов иерархии и задачи пастырей ${ }^{15}$.

11 То же мы видим и в основательной энциклопедической статье: Rousse J. Saint Grégoire de Nazianze // Dictionaire de Spiritualité. Vol. VI. Paris: Beauchesne, 1964. P.932-971. Это позволяет говорить не только о проблемах богословского подхода, но и о том, что эллинский контекст темы священства еще не входит в «общее знание» того времени. В указанной статье тема священства помещена в раздел о таинствах в учении свт. Григория. Хотя при рассмотрении других аспектов творчества Назианзина показаны очень тонкие контекстуальные связи с платонизмом, учением Оригена, Плотина и др. в разделах «Эллинизм», «Созерцание», «Обожение христиан», «“Философия” Григория» и др., раздел о священстве все же носит исключительно богословский характер.

12 Serra M. La caritá pastorale in San Gregorio Nazianzeno // Orientalia Christiana Periodica. 1955. Vol.21. P. 337-374.

${ }^{13}$ Gonçalo Alves de Sousa P. El sacerdocio permanente en la "Oratio II, Apologetica" de San Gregorio Nacianceno // Escritos sobre el carácter sacerdotal / ed. by J.Ibánez. Burgos: Aldecoa, 1974. P. 25-41.

${ }^{14}$ Bellini E. La predicazione in San Gregorio Nazianzeno (a proposito di Oratio II 35, 50) // La Scuola Cattolica. 1963. Vol.9. P. 496-506.

${ }^{15}$ Bellini E. La figura del Pastore d'anime in san Gregorio Nazianzeno // Ibid. 1971. Vol. 99. P.261-296. У этого же автора мы находим анализ экклезиологии свт. Григория: Bellini E. La chiesa nel mistero della salvessa in San Gregorio Nazenzeno. Venegono Inferiore: Seminario Arcivescovile Di Milano, 1970. 
Завершает эту линию книга П. Галло ${ }^{16}$. В ее библиографии присутствует большинство статей того периода. Она содержит перевод 3-го Слова с пространным вступлением. Изданная после подготовленного Ж. Бернарди тома со Словами 1-3 в Sources Chrétiennes (см. ниже) книга не представляет большого интереса, поскольку анализирует тему священства в рамках замкнутой богословской системы, практически вне исторического и интеллектуального контекста эпохи.

Следует обратить внимание на небольшой раздел «Григорий и священство» в монографии французского исследователя П.Галле, изданной в 1964 г. ${ }^{17}$ Как кажется, анализ, направленный преимущественно на структуру и внутреннюю логику «Апологии», позволяет автору глубже понять высказывание свт. Григория. На наш взгляд, методологически более оправданно не только выявлять ключевые категории текста, но и встраивать их в общую логику повествования, подчиненную намерению автора. С такой точки зрения исследования, систематизирующие важный, но не единственный материал, описывающий «величие сана», уступают по научной значимости тем, в которых представлена реконструкция общей логики «Апологии».

Несмотря на повышение интереса к теме священства у свт. Григория, общие патрологические исследования в главах по Богослову не рассматривают ее, фокусируясь на триадологии и христологии ${ }^{18}$.

Конечно, мы не ставили перед собой задачу охватить все работы, где так или иначе упоминалась тема священства у свт. Григория ${ }^{19}$, а постарались рассмотреть лишь те, в которых она имеет ключевое значение.

${ }^{16}$ Gallo P. "Apologeticus de fuga" di San Gregorio Nazianzeno: studio sul sacerdozio e traduzione in italiano. Roma: Pontificia Universitas Lateranense, 1985.

17 Gallay P. Gregor von Nazianz. Stuttgart: Schwabenverl, 1964.

18 См., напр.: Von Campenhausen H. Griechische Kirchenväter. Stuttgart: Kohlhammer Verlag, 1994. S. 101-113; Quasten J. Patrology: in 4 vols. Vol. III. Westminster: Utrecht Spectrum, 1986. Р.243-244 (первое издание в 1950 г.). Последний автор фиксирует влияние Иоанна Златоуста и Григория Великого на тексты о священстве, ничего не говоря о самой «Апологии», в то время как «Шести словам» свт. Иоанна посвящено несколько страниц. Такая картина в патрологии сохраняется и в исследованиях последнего времени. См., напр.: Янг Ф. М. От Никеи до Халкидона. Введение в греческую патристическую литературу и ее исторический контекст. М.: Православный Свято-Тихоновский гуманитарный университет, 2013 (перевод со 2-го изд. англ. оригинала 2010 г., 1-е изд. - 1983 г.); Морескини К. История патристической философии. М.: Греко-латинский кабинет Ю.А.Шичалина, 2011. С. 626-669 (оригинальное итальянское издание - 2004 г.).

19 Приведем пример типичного, как нам кажется, обращения к «Апологии» свт. Григория: Savramis D. Die soziale Stellung des Priesters in Griechenland. Leiden: Brill Archive, 1968. Интересно, что автор считает тексты о священстве учителей Церкви принципиальными для понимания становления современного священства (его анализ выполнен в рамках веберовской парадигмы - священник как носитель авторитета). Однако относительно «Апологии» мы встречаем стандартные штампы: это Слово об «идеальном типе» священника, у свт. Иоанна то же самое, но конкретнее и понятнее, чем у свт. Григория. Далее в книге практически не встречаются обращения к «Апологии» Богослова. Подобный подход можно найти во множестве статей, посвященных феномену священства 


\section{3. Труды Ж. Бернарди}

Ключевая фигура XX в. в изучении творчества свт. Григория - Жан Бернарди, сделавший два важнейших шага на пути изучения темы священства.

Во-первых, он предложил свое понимание логики, которой руководствовался свт. Григорий при формировании корпуса $\mathrm{Cлов}^{20}$, сама постановка вопроса о единой логике всего корпуса Слов встречается здесь впервые $^{21}$. Исследователь делает вывод, что вопрос о цели и обстоятельствах создания конкретного текста должен предваряться вопросом о том, почему он был включен Назианзином в этот корпус. Такой подход, в свою очередь, позволяет указать на должное место темы священства в корпусе святителя: «Это настоящее руководство для епископа (курсив мой. - Н.А.) как оратора, которое он создал, издавая этот корпус Слов» ${ }^{22}$.

Во-вторых, в 1978 г. он издал «Апологию» в серии Sources Chrétiennes ${ }^{23}$. Кроме самого текста, его перевода на французский язык, критического аппарата и анализа рукописной традиции, интерес представляет введение к данному изданию ${ }^{24}$, где присутствуют несколько основополагающих положений. «Апология» - первый крупный текст о священстве; это

вообще. См. напр.: Joussard G. Pour une étude du sacerdoce au temps des Peres // La tradition sacerdotale. Le Puy: X. Mappus, 1959. P. 109-125.

${ }^{20}$ Bernardi J. La prédication des Pères cappadociens: Le prédicateur et son auditoire. Paris: Publications de la Faculté des Lettres et Sciences Humaines de l'Université de Montpellier, 1968. P. 254-260.

21 Удивительно, что последующие исследователи практически не развивали эту линию. В наибольшей степени этот подход, правда без ссылок на текст Ж. Бернарди, присущ прот. Дж. Мак-Гакину в разных его работах (см. ниже).

22 Bernardi J. La predication des Peres cappadociens. P. 257-258.

${ }^{23}$ Gregoire de Nazianze. Discourse 1-3 / ed. by J.Bernardi. Paris: Les Éditions du Cerf, 1978. P. 84-85 (Sources Chrétiennes. Vol.247). - Это издание лежит в основе всех последующих исследований данного текста, см.: Gregorio Nazianzeno. Fuga e autobiografia / ed. by L.Viscanti. Roma: Città nuova, 1987; Gregorio di Nazianzo (san). Tutte le orazioni / eds C. Moreschini, C. Sani, M. Vincelli. Milano: Città nuova, 2000. P. 478-493; Gregor von Nazianz. Priestertum und Bischofsamt: Apologia de fuga sua (Oratio 2) / eds M. Fiedrowicz, C. Barthold. Fohren-Linden: Carthusianus Verlag, 2019. Текстологические дополнения к последнему изданию см. в: Dubuisson M., Macé C.: 1) La place des versions anciennes dans l'histoire du texte de Grégoire de Nazianze. Le cas du Discours 2 // Orientalia christiana periodica. 2002. Vol.68. P.287-340; 2) Lapport des traductions anciennes a l'histoire du texte de Grégoire de Nazianze. Application au Discours 2 // Ibid. 2003. Vol.69. P.287-340. Однако подход последних авторов подвергнут критике в: Бруни А. М. Византийская традиция и старославянский перевод Слов Григория Назианзина. М.: Институт всеобщей истории РАН, 2010. С. 13-35. - В контексте этих исследований важен перевод «Апологии» на латынь, осуществленный Руфином: Tyrannii Rufíni orationum Gregorii Nazianzeni novem interpretation / transl., ed. by A. Engelbrecht. Wien; Leipzig: Vindobonae, F. Tempsky, 1910 (Corpus scriptorum ecclesiasticorum latinorum. Vol.46). - Его исследование см.: Wagner M. Rufinus, the translator. A study of his theory and his practice as illustrated in his version of the Apologética of St. Gregory Nazianzen. Washington: Catholic University of America, 1945.

${ }^{24}$ Bernardi J. Introduction // Grégoire de Nazianze. Discourse 1-3. P. 7-70. 
не автобиографическое Слово, оно не произносилось, но было написано; апология и проповедь - лишь жанровая форма. Ж. Бернарди предлагает анализ категорий $\theta \varepsilon \omega \rho i ́ a / \pi \rho \tilde{a} \xi \iota$, «тирания» и терминологии власти и священства. Автор утверждает, что интересующая нас тема занимает в творчестве свт. Григория место, почти не уступающее по объему учению о Троице (!) ${ }^{25}$; интересным представляется также объединение «Апологии», 42-го и 43-го Слов в своего рода «трилогию о священстве». Ряд аргументов и выводов этой работы кажется нам недостаточно обоснованным ${ }^{26}$, однако постановка вопросов и выделение главных тем значительная заслуга автора.

\section{1990-е годы как завершение XX века}

Прежде чем говорить о новой волне исследований, предвестие которой мы наблюдаем в конце XX в., отметим несколько работ, свидетельствующих о том, что тема священства окончательно занимает свое место в исследованиях творчества свт. Григория.

Во-первых, это монография Лохбруннера, изданная в 1993 г. ${ }^{27}$ Она замечательна не только тем, что серьезно прорабатывает вопрос о влиянии «Апологии» на «Шесть слов» свт. Иоанна Златоуста ${ }^{28}$, но и обстоятельным анализом самого текста свт. Григория.

${ }^{25}$ Bernardi J. Introduction. P. 39.

${ }^{26}$ Например, его рассуждения об аудитории текста, где он говорит о монахах круга свт. Василия как адресатах текста (Ibid. P. 30-31), противоречат его же умозаключениям в предшествующем труде (см. выше о первой монографии Бернарди) и в комментарии к тексту, где на основании одного обращения «мужи» (Ibid. P. 88. Fn. 2) он предполагает, что Слово направлено к «внешней» аудитории.

${ }^{27}$ Lochbrunner M. Über das Priestertum: historische und systematische Untersuchung zum Priesterbild des Johannes Chrysostomus. Bonn: Borengässer, 1993.

${ }^{28}$ См. предшествующие работы по данной теме: Gregorius' von Nazianz Schutzrede und Chrysostomus' 6 Bücher vom Priestertum: zwei pastoraltheologische Schriften der alten Kirche in einer neuen deutschen Übersetzung / Hrsg. G. Wohlenberg. Gotha: Bibliothek theologischer Klassiker, 1890; Volk J. Die Schutzrede des Gregor von Nazianz und die schrift über das Priesterums von Joh. Chrysostomus // Zeitschrift für praktische Theologie. 1895. Bd. 17. S. 56-63; Dorries H. Erneuerung des kirchlichen Amts im vierten Jahrhundert: Die Schrift De sacerdotio des Johannes Chrysostomus und ihre Vorlage, die Oratio de fuga sua des Gregor von Nazianz // Bleibendes im Wandel der Kirchengeschichte / Hrsg. B. Moeller, G. Ruhbach. Tübingen: Mohr, 1973. А также критическое издание: Jean Chrysostome. Sur le sacerdoce (Dialogue et Homélie) / ed. by A.-M. Malingrey. Paris: Les Éditions du Cerf, 1980 (Sources Chrétiennes. Vol.272). После выхода рассматриваемой монографии были написаны статьи: Molac P. Des sources nazianzéennes au discours sur le sacerdoce de Saint Jean Chrysostome // Bulletin de littérature ecclésiastique. 2004. Vol. 105, no. 2. P.169-174; Hofer A. The Reordering of Relationships in John Chrysostom's "De sacerdotio" // Augustinianum. 2011. Vol.51 (2). P.451-471; Mayer W. The persistence in Late Antiquity of medico-philosophical psychic therapy // Journal of Late Antiquity. 2015. Vol. 8, no. 2. P.337-351. - Интересна в этом контексте и статья: Griffith S. Iatros and Medicus: The Physician in Gregory Nazianzen and Augustine // Studia Patristica. 2006. No. 41. P.319-325. 
Замечания о влиянии «Апологии» на последующую традицию весьма часто встречаются в рассматриваемых исследованиях, причем приводятся они в основном без какого-либо обоснования или ссылок на другую литературу ${ }^{29}$. Число «зависимых» текстов может варьироваться от одного (либо «Шесть слов» свт. Иоанна Златоуста, либо «Правило пастырское» свт. Григория Великого) до целого ряда текстов (сюда могут добавляться тексты свт. Амвросия, блж. Августина, прп. Иоанна Лествичника и пр.). При этом практически отсутствуют работы, посвященные конкретному текстуальному анализу, благодаря которому можно было бы не только утверждать, что текст свт. Григория рецепиировался в последующей традиции, но и продемонстрировать характер этой рецепции; значительно проработана лишь линия Богослов - Златоуст.

Отметим два важных достижения Лохбруннера. Кроме рассмотрения общего контекста, структуры текста и обстоятельств его написания, он задается вопросом о цели текста как высказывания, что позволяет ему верно отметить: задачей Назиназина являлась реформа клира $a^{30}$. Этот вывод, в свою очередь, дает ему возможность выстраивать сравнение с текстом Златоуста в указанном направлении, демонстрируя функциональность их текстов. Кроме того, мы видим удачный подход к анализу образа священника «как мозаики» ${ }^{31}$, соответствующий риторической, а не систематической природе самой «Апологии»: попытку выделить схему заменяет рассмотрение основных образов и категорий, стоящих за ними.

Bo-вторых, упомянем две диссертации (магистерскую и $\mathrm{PhD}$ ) 1997 г. по святоотеческому пониманию священства, где текстам свт. Григория уделено особое внимание ${ }^{32}$.

B-третьих, укажем на главу «Священство, епископство» в монографии 1997 г. «Жизнь и учение свт. Григория Богослова» митрополита (тогда иеромонаха) Илариона (Алфеева) $)^{33}$. Анализ «Апологии» в ней не предлагает ничего нового по сравнению с существовавшими на тот момент иссле-

${ }^{29}$ Встречаются ссылки на крупные монографии, в которых эта информация, в свою очередь, подается в общем виде.

${ }^{30}$ Lochbrunner M. Über das Priestertum. S. 55.

${ }^{31}$ Ibid. S. 60.

32 Sparacio P. F. From earth to heaven: an understanding of and vision for ordained ministry as guided by Gregory Nazianzus' Flight to Pontus and further grounded in the Fathers of the Church. PhD Diss. Drew University, 1997 (работа рассматривает патристические тексты в практическом ключе; в ней же имеется последний перевод «Апологии» на англ. яз.); Pouliot J. La paternité spirituelle du sacerdoce chez saint Ambroise de Milan, saint Grégoire de Nazianze et saint Jean Chrysostome. Master Thesis. Québec: Université Laval, 1997 (эта магистерская работа сравнивает тексты о священстве свт. Амвросия, Григория и Иоанна. В ней видно, как аккумулируются и входят «в школу» предшествующие исследования, а тексты свт. Григория (вслед за Бернарди - or. 2, 42 и 43) однозначно встают в один ряд c «De Officiis» и «De sacerdotio»). Здесь же можно упомянуть диссертацию, в которой гл. 5 посвящена текстам свт. Григория: Hartless B. “The art of arts and the science of sciences": the cure of the soul and the leadership role of the clergy. PhD thesis. London: King's College, 2014.

${ }^{33}$ Иларион (Алфеев), иером. Жизнь и учение свт. Григория Богослова. М.: Издательство Сретенского монастыря, 1997. 
дованиями, однако важен как очевидный маркер входа темы священства в общее знание.

\section{5. Монографические исследования}

Обозревая исследования наследия свт. Григория за XIX-XX вв., нельзя не сказать о крупных работах, посвященных ему, среди которых выделяются три типа исследований.

Первый тип можно обозначить как изложение идей святителя через призму догматической системы ${ }^{34}$. В таких трудах авторы не обращаются к теме священства, поскольку, по их мнению, она не является частью этой системы.

Bторой тип объединяет несколько монографий о биографии свт. Григория. В них не просто предлагается жизнеописание святителя, но поэтапно показывается связь между его творчеством, жизнью и более широким историко-культурным контекстом ${ }^{35}$. Анализ темы священства в работах такого типа весьма ограничен и связывается с кратким рассмотрением «Апологии» в ее биографическом аспекте и, реже, с последними периодами жизни Богослова и его критикой епископата.

В работах mретьего muna ${ }^{36}$ делается акцент на античном контексте творчества святителя, что чаще всего выражено через дихотомию «элли-

${ }^{34}$ См., напр.: Plagnieux J. St. Grégoire de Nazianze théologien. Paris: Franciscaines, 1952. - Выше назывались работы: Ullmann C. Gregor von Nazianz, der Theologe; Иларион (Алфеев), иером. Жизнь и учение свт. Григория Богослова.

35 См., напр.: Порфирий (Попов), архим. Жизнь святого Григория Богослова // Труды Киевской духовной академии. 1863. № 4. С.400-430; Benoit A. Saint Grégoire de Nazianze. Sa vie, ses oeuvres, et son époque. Marseille, 1876 (Reprint: New York: Hildesheim, 1973); Kpyzлов А. В. Св. Григорий Богослов: Очерк жизни и деятельности. М.: Типография И.Н.Кушнерева и Ко, 1899; Четыркин Ф. В. Св. Григорий Богослов. СПб.: Типография Ф. Елеонскаго и $\mathrm{K}^{\circ}$, 1895; Fleury E. Saint Gregoire de Nazianze et son temps: hellénisme et christianisme. Paris: Beauchesne, 1930 (достаточно похожая по построению на книгу Бенуа, эта работа показывает качественно другой уровень анализа интеллектуального контекста творчества Назианзина, в основном за счет влияния Пино (см. ниже); здесь мы видим смешение второго и третьего типов: автор рассматривает интеллектуальную биографию свт. Григория в свете оппозиции «эллинизм - христианство», что и вынесено в заглавие книги); Gallay P. La vie de saint Grégoire de Nazianze. Lyon: E. Vitte, 1943; Bernardi J. Saint Grégoire de Nazianze. Le Théologien et son temps (330-390). Paris: Les Éditions du Cerf, 1995; Trisoglio F. Gregorio di Nazianzo il teologo. Milano: Vita e penserio, 1996. - Особо следует назвать монографию, в которой, не занимаясь специально нашей темой, автор отмечает постоянную рефлексию свт. Григория относительно священства, а также высказывает важный тезис: свт. Григорий связывал мысли о христианской традиции и экклезиологии с проблемами клира, тем самым показывая, сколь значимо место темы священства в мысли свт. Григория (McGuckin J. Saint Gregory of Nazianzus: An Intellectual Biography. New York: St Vladimir's Seminary Press, 2001).

${ }^{36}$ См., напр.: Gottwald R. De Gregorio Nazianzeno platonico. Vratislaviae: H. Fleischmann, 1906; Pinault H. Le platonisme de St. Grégoire de Nazianze. La Roche-Sur-Yon: G. Romain, 1925 (здесь мы нашли полезным, например, сопоставление «аскетического» абзаца из «Апологии» (or. 2.7) с фрагментами из «Эннеад» Плотина); Ruether R. R. Gregory of Nazianzus. Rhetor and Philosopher. Oxford: Clarendon Press, 1969. Рютер благодаря такой 
низм - христианство»: богословские концепты сравниваются с философской платонической традицией, анализируется риторическая составляющая речей свт. Григория и связь всего его творчества с классическими образцами. Тема священства начинает рассматриваться под таким углом достаточно поздно. Несмотря на это, именно здесь произошла разработка философского контекста категориального аппарата свт. Григория, что дало в XXI в. целый ряд работ, устанавливающих связь между темой священства и философским контекстом эпохи.

\section{6. Новая волна исследований: 1990-е годы как начало XXI века}

Чтобы объяснить количественный и качественный рост работ по теме настоящей статьи в последние десятилетия, помимо работ Бернарди, нужно указать на общее методологическое изменение в исследованиях той эпохи. Период поздней Античности выделяется как самостоятельный феномен со своей социальной и интеллектуальной спецификой, и в центре внимания исследователей оказывается вопрос о природе власти (power, leadership, authority), изучаемый на примере текстов позднеантичных авторов. Такая точка зрения предлагает во многом новое прочтение античной философии ${ }^{37}$, что, в свою очередь, позволяет увидеть новые связи между ней и христианскими текстами о священстве ${ }^{38}$.

Ключевой фигурой этого процесса можно назвать Питера Брауна. Не оценивая его интеллектуальное влияние на тему статьи, поскольку оно было опосредованным, отметим, что многие авторы возводят свою интеллектуальную биографию именно к нему, а две из приведенных нами ниже монографий опубликованы в серии «Transformation of the Classical Heritage» ${ }^{39}$, главным редактором которой является П.Браун. Даже беглое знакомство с входящими в эту серию монографиями дает общее представление об основных подходах этой научной традиции. Кроме того, группа исследователей, чьи работы мы будем рассматривать ниже, характеризует-

оптике едва ли не первой отмечает, что путь священства свт. Григорий понимал как синтез практической жизни и созериательной, осмысляемый в платоническом контексте (Ibid. P.28-33). Moreschini C. Filosofia e letteratura in Gregorio di Nazianzo. Milano, Vita e pensiero, 1997. Морескини, рассматривая творчество Богослова с точки зрения синтеза классических античных и христианских представлений, обходит стороной учение о священстве, лишь вкратце упоминая о нем при рассмотрении «Апологии» свт. Григория.

37 Исследования власти в этом ракурсе дали, например, монографию: O’Meara D.J. Platonopolis: Platonic Political Philosophy in Late Antiquity. Oxford: Oxford University Press, 2003.

38 Несмотря на значительную разработанность связей терминологического аппарата свт. Григория с платонической философией (обожение, созерцание, деятельная жизнь, образование и т. д.), исследователи не рассматривали в этом контексте тему священства.

39 Transformation of the Classical Heritage. URL: https://www.ucpress.edu/series/tch/ transformation-of-the-classical-heritage (дата обращения: 10.05.2021). 
ся частым взаимным цитированием, участием в ряде совместных монографий и сборников статей ${ }^{40}$.

Значительным событием в изучении епископата IV-V вв. стал сборник 1997 г. «Епископы и пастыри в эпоху императора Феодосия», в котором пять статей раскрывают тему священства у свт. Григория ${ }^{41}$.

Особое внимание хочется уделить статье отца Эндрю Лаута; небольшая и изящно выстроенная, она дает целостную характеристику интересующей нас тематики. Биография свт. Григория описывается с точки зрения продвижения по церковной иерархии, также автор указывает на аристократическую неприязнь к вышедшим из низших классов епископам как на важный элемент бэкграунда свт. Григория. Кроме того, отмечается двойственность использования слова філобофі а и всей мысли Назианзина, заключающейся в сочетании аскетических и аристократических коннотаций. Э. Лаут показывает, что сочинения Платона (особенно «Федр», «Теэтет» и «Государство») являлись для Богослова прототекстом в осмыслении священства как философского пути; из анализа фрагментов 21-го (о свт. Афанасии) и 43-го (о свт. Василии) Слов автор делает вывод, что идеал этой философской жизни свт. Григорий мог увидеть только в другом человеке.

Из других статей видно, как тема священства начинает рассматриваться на материале отдельных текстов более подробно. Статья Н. Мак-Линна стоит первой в ряду работ, демонстрирующих, что после оставления Константинопольского престола свт. Григорий не устраняется от церковной политики (распространенный в литературе штамп), но продолжает активно участвовать в ней своими литературными произведениями, причем их основная тема и адресаты - епископат ${ }^{42}$. Две другие статьи рассматривают критику епископата в автобиографических поэмах и образ свт. Афанасия из 21-го Слова как модель епископа.

${ }^{40}$ Некоторые из них, посвященные свт. Григорию, мы рассмотрим ниже, здесь же как пример связи этих исследователей с П. Брауном приведем небезынтересный сборник: Transformations of Late Antiquity: Essays for Peter Brown / eds P. Rousseau, M. Papoutsakis. London: Routledge, 2009.

${ }^{41}$ Louth A. St. Gregory Nazianzen on Bishops and the Episcopate // Vescovi e pastore in epoca Teodosiana: in 2 vols. Vol. II. Rome: Institutum Patristicum Augustinianum, 1997. P.281-285; Demoen K. Acteurs de pantomimes, trafiquants du Christ, flatteurs de femmes... Les évêques dans les poèmes autobiographiques de Grégoire de Nazianze // Ibid. P.287-298; McLynn N. B. The Voice of Conscience: Gregory Nazianzen in Retirement // Ibid. P. 299-308; Pouchet J.-R. Athanase d'Alexandrie, modele de l'évêque, selon Grégoire de Nazianze, Discours 21 // Ibid. P. 347-358; Villegas N. G. La corte de Constantinopla y su Obispo. A propósito de la Or. 36 de Gregorio de Nacianzo // Ibid. P. 359-370.

${ }^{42}$ См. чуть более раннюю статью: Bernardi J. Trois autobiographies de saint Gregoire de Nazianze // L'invention de l'autobiographie: d'Hésiode à Saint Augustin / eds M. F. Baslez, P. Hoffmann, L. Pernot. Paris: Rue d’Ulm, 1993. P. 155-165. Автор подчеркивает педагогическую направленность автобиографических текстов, написанных после Константинопольского собора 381 г. Такое видение хорошо дополняет более позднюю тенденцию усматривать в этих текстах апологически-политическое высказывание. 
К этому можно добавить вышедшие в 1999 и 2000 гг. ранние статьи С. Эльм ${ }^{43}$, посвященные 42-му и 43-му Словам Богослова ${ }^{44}$.

Работа по выделению различных аспектов и связей темы священства активно шла на протяжении двух последних десятилетий. Появилось несколько текстов с полным обзором источников свт. Григория и концепциями, в рамках которых эта тема вписывается в ту или иную интеллектуальную сферу поздней Античности. Мы выделили три концептуальных подхода с условными названиями: «монашество-епископат», «политическая философия», «богословский ответ».

Первые две группы, хотя авторы обеих тесно связаны друг с другом ${ }^{45}$, формируются исходя из анализа тех фрагментов, где свт. Григорий обращается к оппозиции $\theta \varepsilon \omega \rho i ́ \alpha-\pi \rho \tilde{\alpha} \xi \varsigma^{46}$. Представляется необходимым кратко показать, как эта тема рассматривалась в исследовательской литературе.

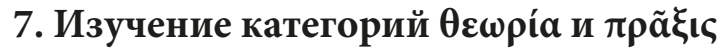

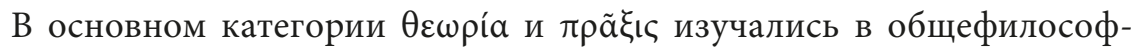
ском контексте ${ }^{47}$. Важно подчеркнуть, что их рассмотрение происходило в отрыве от анализа темы священства. Это, на наш взгляд, яркое свидетельство того, что она находилась у исследователей в «слепом пятне», поскольку сегодня очевидна тесная взаимосвязь представлений свт. Григория о практической и созерцательной жизни и священстве $\mathrm{e}^{48}$. Отметим здесь, кроме множества статей на эту тему ${ }^{49}$, монографию 1971 г. «Григо-

${ }^{43}$ Elm S.: 1) Inventing the Father of the Church: Gregory of Nazianzus' "Farewell to the Bishops" (Or. 42) in its Historical Context // Vita Religiosa im Mittelalter / eds F. Felten, N. Jaspert. Berlin: Duncker \& Humblot, 1999. P.3-20; 2) A Programmatic Life: Gregory of Nazianzus' Orations 42 and 43 and the Constantinopolitan Elites // Arethusa. 2000. Vol.33, no. 3. P.411427. - Этому же Слову посвящена статья: McLynn N. Gregory Nazianzen's Basil: The Literary Construction of a Christian Friendship // Studia Patristica. 2001. Vol. 37. P. 178-193.

${ }^{44}$ Характерно, что следующая ее статья исследует «Апологию», а именно эти три текста Бернарди соединил в своего рода «трилогию о священстве».

45 Три ключевых автора этих групп - А. Стерк, К. Рапп и С. Эльм - так или иначе восходят к П. Брауну. В их монографиях можно увидеть все четыре указанные фамилии, а в тексте - частые ссылки на работы друг друга.

46 Эти фрагменты они находят в основном в «Апологии», особенно or. 2.6-7, и во фрагментах из Слов о свт. Василии (43) и свт. Афанасии (21). Фрагмент из «Апологии» является одним из самых «пререкаемых» и тем самым показательных, так как часть исследователей прочитывает его исключительно в платоническом контексте, а часть в «монашеском», считая, что в нем идет речь о ранних аскетических опытах свт. Григория и свт. Василия.

${ }^{47}$ См. выше п. 5 о «третьем типе» монографий.

${ }^{48}$ Выше мы говорили, что уже для отечественного исследователя XIX в. П. Борисовского рассмотрение «созерцательной и практической жизни» в трудах свт. Григория необходимо связывалось с анализом темы священства.

${ }^{49}$ Cм., напр.: Szymusiak J. M. Amour de la solitude et vie dans le monde à l'école de St. Grégoire de Nazianze // La vie spirituelle. 1966. Vol.114. P.129-160; Špidlík T. La theoria et praxis chez Grégoire de Nazianze // Studia psatristica. 1971. Vol.14. P.358-364; Kertsch M. Gregor von Nazianz' Stellung zu "Theoria” und "Praxis" aus der Sicht seiner Reden // Byzantion. 
рий Богослов: введение в исследования его духовного учения» ${ }^{50}$, которая

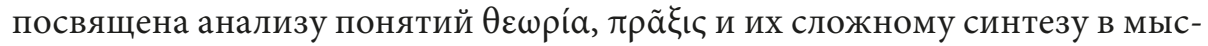
ли свт. Григория.

Бо́льшую часть работ такого рода объединяют три идеи: 1) слово «философия» обозначает в контексте этих понятий образ жизни, а не учение; 2) «в классическом понимании» данные понятия отражают два различных, противопоставленных образа жизни; 3) свт. Григорий предлагает некоторый синтез этих образов жизни ${ }^{51}$. Однако раскрытие каждого из положений может значительно отличаться в зависимости от контекста, в котором рассматриваются эти категории.

Переход к теме священства в подобных исследованиях отчасти осуществлен благодаря рассмотрению образа Моисея в трудах отцов-каппадокийцев ${ }^{52}$. Становление Моисея в их интерпретации сочетало три этапа: образование, созерцание, духовное руководство, - именно это служило для них образцом идеального становления епископа.

Окончательно связь между платоническим и аскетическим контекстами этих категорий и их роль в осмыслении пути священства в текстах свт. Григория зафиксировал французский исследователь Ф. Готье ${ }^{53}$. Об этом говорится в первой части его монографии «Христианская философия у Григория», где он анализирует не только категории $\theta \varepsilon \omega \rho i ́ \alpha, \pi \rho \tilde{a} \xi \iota \varsigma$,

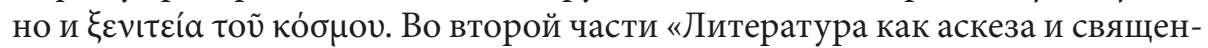
ство» рассматриваются общий литературный контекст эпохи, представления свт. Григория о «пайдейе» и его автобиографические произведения. Демонстрируется, что Богослов осмыслял свое литературное творчество как церковное служение и аскетическую практику. Эти две части дают полное понимание контекста и являются, пожалуй, лучшей базой для постижения логики свт. Григория.

1974. No. 44. P.282-289; Oosthout H. La vie contemplative: vie d'ascète ou vie de théologien? Purification et recherche de Dieu chez Athanase d'Alexandrie et Grégoire de Nazianze // Fructus Centesimus / ed. by A. R. Bastiaensen. Turnhout: Brepols Publishers, 1989. P. 258-267.

${ }^{50}$ Špidlík T. Grégoire de Nazianze: introduction à létude de sa doctrine spirituelle. Roma: Orientalia Christiana Analecta, 1971.

${ }^{51}$ Интересный взгляд представлен у Рютера, который, как отмечалось выше, едва ли не первый показал, что подобный синтез свт. Григорий относил к пути священства. Мысль эта однако не развита у него. Другим значительным его достижением стала демонстрация того, что свт. Григорий выстраивал не «гностическую» систему, где есть истинные христиане-созерцатели и все остальные; он представил в своем творчестве идею многих путей в Церкви (Ruether R. R. Gregory of Nazianzus. Rhetor and Philosopher. P. 136-155). Этой идее мы уделим особое внимание.

52 См., напр.: Harl M. Les trois quarantaines de la vie de Moïse, schéma idéal de la vie du moine-évêque chez les Pères Cappadociens // Revue des Études Grecques. 1967. Vol. 80. P. 407412; Sterk A. On Basil, Moses, and the Model Bishop: The Cappadocian Legacy of Leadership // Church History. 1998. Vol.67. P.227-253; Rapp C. Comparison, Paradigm and the Case of Moses in Panegyric and Hagiography // The Propaganda of Power / ed. by M. Whitbe. Leiden; Boston; Köln: Brill, 1998. P.277-298.

${ }^{53}$ Gautier F. La retraite et le sacerdoce chez Grégoire de Nazianze. Turnhout: Brepols, 2002. 


\section{8. Работы о монашестве-епископате}

Работы, которые мы объединили в этой группе, рассматривают творчество свт. Григория с точки зрения отражения в нем сложных процессов становления, развития и взаимовлияния двух основных институтов церкви - епископата и монашества. Количество работ на эту тему неисчерпаемо, и многие из них обращаются к текстам свт. Григория ${ }^{54}$. Мы же рассмотрим лишь монографии, содержащие разделы, целиком посвященные нашей теме, и предлагающие оригинальный взгляд на материал.

В монографии 2004 г. А. Стерк показывает, как образ «монаха-епископа» становится нормативным образцом для церковного лидера ${ }^{55}$. Первые две главы посвящены процессу оформления такого понимания в текстах свт. Василия, Григория Богослова, Григория Нисского и Иоанна Златоуста. В третьей главе рассматривается история дальнейшего закрепления этого идеального образа. Названная работа делает очень важный методологический шаг: исследователь концентрируется на текстах и представлениях святителей Церкви, а не на их исторической деятельности.

В разделе о Назианзине предлагается весьма полный анализ темы священства на материале основных текстов святителя, среди которых все Слова о принятии новых должностей (Or. 2, 9-12), близкие по тематике Слова о свт. Афанасии и свт. Василии (Or. 21 и 43), ранние письма к свт. Василию (особенно Ep. 7), поэмы «De vita sua», «De se ipso et de episcopis» и др. Из этого списка особое внимание уделяется «Апологии» и надгробному Слову о свт. Василии. А. Стерк, будучи, без сомнения, знакома с «эллинскими» прочтениями термина «философия» и вообще аскетической лексики в творчестве свт. Григория ${ }^{56}$, трактует их исключительно как относящиеся к монашескому образу жизни, указывая, что, несмотря на философские корни этой лексики, «все последующие читатели видели в образе епископа черты философа современного им - общежительного монаха» ${ }^{57}$. Такое прочтение имеет свои основания, однако не является единственно возможным.

Монография К.Рапп «Святые епископы в поздней Античности» - едва ли не самая влиятельная работа в исследованиях епископата последнего

${ }^{54}$ См., напр.: Patrucco M. F. Bishops and Monks in Late Antique Society // Zeitschrift für Antikes Christentum. 2005. No. 8. Р.332-345 (где свт. Григорий является одним из главных героев); Gwynn D. M. Episcopal Leadership // The Oxford Handbook of Late Antiquity / ed. by S.F. Johnson. Oxford: Oxford University Press, 2012 (эта статья во многом аккумулирует идеи из рассматриваемых ниже монографий).

${ }^{55}$ Sterk A. Renouncing the World, yet Leading the Church: The Monk-Bishop in Late Antiquity. Cambridge: Harvard University Press, 2004. В том же ключе «Апология» рассматривается в: Hornung C. Monachus et sacerdos. Asketische Konzeptualisierungen des Klerus im antiken Christentum. Leiden; Boston: Brill, 2020. P. 38-46.

${ }^{56}$ Например, она ссылается статью С.Эльм 2001 г.: Elm S. Orthodoxy and the Philosophical Life: Julian and Gregory of Nazianzus // Studia Patristica. 2001. Vol. 37. P. 69-85.

57 Sterk A. Renouncing the World, yet Leading the Church. P. 140. 
времени ${ }^{58}$. Помимо обстоятельного обзора литературы о епископате, в первой части работы исследовательница предложила свою модель обоснования авторитета епископа в поздней Античности, а во второй - определенное прочтение исторического материала, исходящее из этой модели. Хотя сам по себе анализ творчества свт. Григория после Ф. Готье и А. Стерк не представляет большого интереса, включение его в круг текстов свт. Иоанна, Амвросия, Григория Великого и др., выделение ряда общих тем и образов демонстрируют значение свт. Григория в этом дискурсе.

Дж.Демакопулос, основываясь на исследованиях А.Стерк и К.Рапп, в монографии 2007 г. рассматривает взаимовлияние монашества и епископата с точки зрения осмысления их как носителей функции духовного руководства ${ }^{59}$. Второй раздел книги, посвященный духовному руководству у Назианзина, представляет собой весьма полный обзор концепции авторитета епископа и его деятельности в рамках духовного руководства. Недостатком работы можно считать то, что термины authority, leadership, spiritual direction достаточно проблематичны для приложения их к реалиям IV-V вв. Если в указанных выше работах они были частью рефлексии исследователей, то здесь выглядят недостаточно проработанными. Значительный плюс работы заключается в очерчивании, помимо уже устоявшихся категорий, относящихся к авторитету священника (возраст, образование, аристократизм, синтез созерцательной и практической жизни и т.д.), области деятельности пресвитера/епископа с включением этой деятельности в исторический контекст. Одним из центральных пунктов здесь было привлечение 14-го Слова («О любви к бедным») как программного для деятельности всех каппадокийцев. Включение филантропии в деятельность епископа (не столько личные дела, сколько формирование определенного этического императива у общины) обусловливает его новое место в античном социуме ${ }^{60}$.

${ }^{58}$ Rapp C. Holy Bishops in Late Antiquity. Berkley: University of California Press, 2005. Эта монография входит в вышеупомянутую серию «The Transformation of the Classical Heritage», главным редактором которой является П. Браун.

59 Demacopoulos G. E. Five Models of Spiritual Direction in the Early Church. Notre Dame: University of Notre Dame Press, 2007.

${ }^{60}$ Исследования данного процесса даже на материале только 14-го Слова достаточно обширны, см., напр.: Winslow D. F. Gregory of Nazianzus and Love for the Poor // Anglican Theological Review. 1965. Vol. 47. P. 348-359; Daley B. E. Building a New City: The Cappadocian Fathers and the Rhetoric of Philanthropy // Journal of Early Christian Studies. 1999. No. 7. P. 431461; Matz B. J. Deciphering a Recipe for Biblical Preaching in Oration 14 // Re-Reading Gregory of Nazianzus / ed. by C. Beeley. Washington: Catholic University of America Press, 2012. P. 4966. - Особо выделим блестящую статью прот. Дж. Мак-Гакина: McGuckin J. St. Gregory of Nazianzus on the Love of the Poor (Oration 14) // The Ecumenical Legacy of Cappadocians / ed. by N. Dumitrascu. New York: Palgrave Macmillan, 2015. P. 139-157. - Нельзя не отметить и монографию: Brown P. Poverty and Leadership in the Later Roman Empire. Hanover: University Press of New England, 2002. 


\section{9. Политическая философия}

Являясь плотью от плоти того движения, которое мы обозначили как новую волну, С.Эльм изначально работала в схожем направлении. Первая ее монография рассматривает становление христианского монашества ${ }^{61}$, а ранние статьи по теме священства у свт. Григория выполнены в схожей парадигме. Однако, перейдя к сравнению текстов святителя с текстами императора Юлиана, она обнаружила, что святитель и император, находясь по разную сторону баррикад, говорят об одинаковых проблемах на общем философском языке. Это сопоставление, начавшееся с одной статьи ${ }^{62}$, привело к изданию в 2012 г. монографии, без которой исследования творчества свт. Григория сейчас слабо представимы ${ }^{63}$.

Для нашего обзора интересны три ее положения.

Во-первых, исследовательница аргументировала прочтение всей терминологии святителя, связанной с философией/аскезой в платоническом ключе, путем ее сопоставления с идеями императора Юлиана, имевшего схожее образование. Такой подход более предпочтителен при интерпретации текстов Богослова, нежели подход А. Стерк, основанный на сопоставлении с последующей христианской традицией. Таким образом, С.Эльм окончательно зафиксировала, что свт. Григорий говорил о священстве в категориях философского пути, описывая этот статус в традиционных философских топосах ${ }^{64}$. Сюда же можно отнести рассмотрение образования как одной из ключевых категорий мысли свт. Григория о священстве ${ }^{65}$.

${ }^{61}$ Elm S. "Virgins of God": The Making of Asceticism in Late Antiquity. Oxford: Oxford University Press, 1994.

${ }^{62}$ Elm S. Orthodoxy and the Philosophical Life: Julian and Gregory of Nazianzus. P. 6985. Затем вышли достаточно близкие по содержанию статьи: Elm S.: 1) Hellenism and historiography: Gregory of Nazianzus and Julian in dialogue // Journal of Medieval and Early Modern Studies. 2003. Vol.33. P.493-515; 2) Historiographic Identities: Julian, Gregory of Nazianzus, and the Forging of Orthodoxy // Zeitschrift für antikes Christentum. 2003. Vol.7. P. 249-266. - Нельзя не отметить первую статью С. Эльм, посвященную «Апологии», где автор показывает, как прочтение «Апологии» в контексте 6-го Слова проясняет позицию свт. Григория: Elm S. The diagnostic gaze. Gregory of Nazianzus' theory of orthodox priesthood in his Orations 6 De pace and 2 Apologia de fuga sua // Orthodoxy, Christianity, History / eds S. Elm, E. Rebillard, A. Romano. Roma: École Française de Rome, 2000. P. 83-100.

${ }^{63}$ Elm S. Sons of Hellenism, fathers of the church: Emperor Julian, Gregory of Nazianzus, and the vision of Rome. Berkley, LA; London: University of California Press, 2012. - Эта монография также входит в серию «The Transformation of the Classical Heritage». Для этого типа исследований значима первая монография выдающегося исследователя: Lizzi Testa R. Il potere episcopale nell'Oriente romano. Roma: Filologia e critica, 1987.

${ }^{64}$ См. вторую часть монографии: Elm S. Sons of Hellenism. P. 147-268 (особенно P. 153-166).

${ }^{65}$ См. также: Bernardi J. Un regard sur la vie Étudiante à Athènes au milieu du IVe s. après J.-C. // Revue des Études Grecques. 1990. Vol. 103. P.79-94; Limberis V. "Religion" as the cipher for identity: the cases of emperor Julian, Libanius, and Gregory Nazianzus // Harvard Theological Review. 2000. Vol.93, no. 4. P. 373-400; Wenzel A. Libanius, Gregory of Nazianzus, and the Ideal of Athens in Late Antiquity // Journal of Late Antiquity. 2010. Vol. 3 (2). P.264-285; Watts E. Education: Speaking, Thinking and Socializing // The Oxford Handbook of Late Antiquity / ed. by 
Во-вторых, она определила тему священства как ключевую во всем творчестве свт. Григория с выделением круга текстов по этой теме. Фактически именно С. Эльм показала, что учение о священстве - не просто один из разделов творчества святителя, но структурообразующая тема во всем его творчестве, поскольку именно она делает все его наследие единым высказыванием ${ }^{66}$.

B-третьих, она продемонстрировала, что это высказывание было осуществлено в рамках политической философии, т.е. мысли о наилучшем устройстве ойкумены, причем и для свт. Григория, и для имп. Юлиана ключевой категорией политической философии было «обожение» ${ }^{67}$, поскольку лишь достигший обожения философ/священник может привести людей к правильному богопочитанию - залогу процветания ойкумены.

Исследования сотериологии и терминологии обожения в текстах святителя имеют долгую историю и выполнялись в основном в русле сопоставления с текстами Платона и Плотина, практически не рассматривая связь этой категории с темой настоящей статьи ${ }^{68}$.

Однако С.Эльм и ее коллега Б.Маслов показали, что в интерпретации свт. Григория концепт «обожение» формировался под влиянием стоического учения; это позволило выявить связи этого концепта с темой священства ${ }^{69}$. Предшествующие исследователи уже зафиксировали,

F. S. Johnson. Oxford: Oxford University Press, 2012. Van Hoof L., Nesselrath H. G. The reception of Libanius from Pagan friend of Julian to (almost) Christian Saint and back // Libanius: a critical introduction. New York: Cambridge University Press, 2014. P. 160-183.

${ }^{66}$ Elm S. Sons of Hellenism. P. 156-157.

67 Отметим статью русского исследователя по этой теме: Бирюков Д. С. Вера - язык: Юлиан и свт. Григорий Назианзин // Император Юлиан: сочинения / ред. Д. С. Бирюков. СПб.: Издательство Санкт-Петербургского университета, 2007. С.55-90. - Подробнее о происхождении этого дискурса см.: O’Meara D. J. Platonopolis...

68 Эта тема внимательно рассмотрена в работах, посвященных анализу текстов свт. Григория в эллинистическом контексте, и специально в работе: Winslow D.F. The Dynamics of Salvation: A Study in Gregory of Nazianzus. Cambridge, Massachusetts: The Philadelphia Patristic Foundation, 1979. - К теме обожения в учении свт. Григория обращается H. Рассел: Russel N. The Doctrine of Deification in the Greek Patristic Tradition. Oxford: Oxford University Press, 2004. P.213-224. Он достаточно точно указывает на роль священника как посредника в таинствах, отмечая, что это отличает христианскую концепцию от философской. См. также несколько статей из сборника: Partakers of the Divine Nature: The History and Development of Deification in the Christian Traditions / eds M. J. Christensen, J. A. Wittung. Madison: Baker Academic Publ., 2007.

${ }^{69}$ Исследователи участвовали в семинаре (The Oxford Byzantine seminar) в 2011 г., что отмечено в благодарностях обоих авторов. В данном случае мы обращаемся к статьям Б. Маслова, поскольку они представляются наиболее полным, конкретным и лаконичным изложением достаточно солидного материала: Maslov B.: 1) The Limits of Platonism: Gregory of Nazianzus and the Invention of theōsis // Greek, Roman, and Byzantine Studies. 2012. No. 52. P. 440-468; 2) Oikeiōsis pros theon: Gregory of Nazianzus and the heteronomous subject of Eastern Christian penance // Journal of Ancient Christianity. 2012. No. 16 (2). P.311-343. Кроме соответствующих глав в монографии, у С.Эльм вышли две статьи в сборниках, в значительной мере текстуально совпадающие друг с другом: Elm S. 1) Priest and Prophet: Gregory of Nazianzus's Concept of Christian Leadership as Theosis // Priests and Prophets 


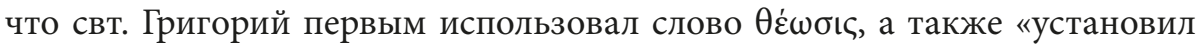
сущностную связь между обожением и этическим прогрессом отдельного верующего ${ }^{70}$. Однако исследователь переносит внимание с лексики, на основании которой концепт обожения у свт. Григория прочитывался

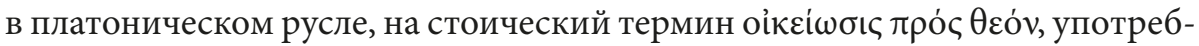
ляемый свт. Григорием на разных уровнях для описания трехчастных отношений: Бог - священник - человек; Бог Отец - Христос - человек; Бог - душа - тело ${ }^{71}$. На материале «Апологии» Б. Маслов показывает, что свт. Григорий разрабатывал не столько философско-монашескую тематику, о которой мы говорили выше (хотя и здесь он предложил свое понимание философии как образа жизни в рамках христианской этики), сколько

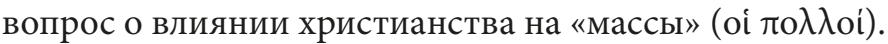

Для понимания логики святителя Б. Маслов предложил обратиться к идее «двойственной этики», взятой из «Евангельского доказательства» Евсевия Кесарийского (Eusebius. Demonstratio evangelica. 1.8), легализирующей различие клира и мирян в модусах жизни (брак, участие в общественной жизни, включая власть и войну, и т.д. как пункты различия). Развитие этой идеи у свт. Григория поднимает вопрос о природе власти клира, способах и целях его действия. Полагаем, анализ отличия такого устроения общества от философских проектов показывает коренные изменения общества поздней Античности и необходим для понимания формирования церковной идентичности, однако воздержимся от далекоидущих выводов.

\section{0. Богословский ответ}

Прежде чем перейти к трем монографиям ${ }^{72}$, развивающим богословский подход к творчеству свт. Григория и написанным как бы в ответ авторам предыдущих «групп», укажем, что в «традиционных» богословских работах, исследующих экклезиологию ${ }^{73}$ и историю развития церковной

among Pagans, Jews and Christians / eds B.Dignas, R.Parker, G. G. Stroumsa. Leuven; Paris; Walpole: Peeters, 2013. P. 162-184; 2) Gregory of Nazianzus: mediation between individual and community // Group Identity and Religious Individuality in Late Antiquity / ed. by E. Rebillard. Washington: Catholic University of America Press, 2015. P. 89-107.

${ }^{70}$ Maslov B. Limits of Platonism. P. 441.

${ }^{71}$ Maslov B. Oikeiōsis pros theon... Р. 330. Сюда же можно добавить: Бог - ум - душа.

72 Кроме них, следует упомянуть работу, где в разделе «Григорий - священник» предложен достаточно полный обзор темы священства, построенный как набор цитат из разных текстов Святителя с комментариями (Daley B.E. Gregory of Nazianzus. Early Church Fathers. London: Taylor \& Francis, 2006. P. 50-61). Также назовем монографию, в которой автор рассматривает использование свт. Григорием библейского материала, в частности в «Апологии» (Matz B. J. Gregory of Nazianzus. Michigan: Baker Books, 2016). Этот анализ показался нам довольно поверхностным, поскольку предлагает лишь некоторую систематизацию библейского цитирования, не вскрывая установок, за ним стоящих. См. его же раннюю статью: Matz B. J. Philippians 2:7 as Pastoral Example in Gregory Nazianzen's Oration 12 // Greek orthodox theological review. 2004. Vol. 49 (3-4). P. 279-290.

${ }^{73}$ Работ, специально посвященных экклезиологии свт. Григория, не так много, что обусловлено спецификой его мысли. Можно назвать и упомянутую выше монографию: 
иерархии ${ }^{74}$, авторы также обращаются к текстам святителя; тем не менее мы не станем анализировать труды такого рода. Во-первых, это практически необозримый материал, а во-вторых, и объект, и метод исследования в них значительно отличаются от интересующих нас. Также мы не станем рассматривать целый корпус богословских текстов по пастырскому/практическому богословию, поскольку они по своему жанру подходят к материалу принципиально по-иному ${ }^{75}$.

Монография К.Били 2008 г. $^{76}$, помимо целого ряда достоинств, интересна для нас своей гл. 5 «Пастырское служение» («Pastoral ministry») ${ }^{77}$. Хотя полемичность этой работы не проговаривается, можно заметить, что автор, будучи прекрасно знакомым с рассмотренными выше исследованиями (более того, достаточно активно на них ссылаясь), строит свое исследование в классическом богословском ключе. Достаточно неожиданным кажется здесь появление упомянутой гл. 5 после традиционных разделов

Bellini E. La chiesa nel mistero della salvessa in San Gregorio Nazenzeno. Отметим статью, в которой автор подчеркивает неэкклезиологический характер текстов свт. Григория, анализируя тем не менее целый ряд образов и метафор, использованных свт. Григорием при упоминании Церкви: Hartmann C. Aus einem Funken das himmlische Licht - Gedanken zur Ekklesiologie Gregors von Nazianz // Vaeter der Kirche. Ekklesiales Denken von den Anfaengen bis in die Neuzeiten / Hrsg. J.Arnold, R.Berndt, R.Stammberger. Padeborn; Muenchen; Wien; Zuerich: Ferdinand Schöningh, 2004. S.217-239. См. также статьи: Honigsberg A. E. A City by Any Other Name...? Gregory of Nazianzus' Constantinople // Studia Patristica. 2006. Vol.41. Р.357-362. Принципиальными представляются работы Г.Е.Захарова, в которых экклезиология свт. Григория представлена в общем контексте его мысли: Захаров Г.Е.: 1) «...Ибо надлежит быть и разномыслиям между вами»: экклезиологическая проблематика в истории арианских споров. М., 2013. С. 105-110; 2) Образ Константинополя в творениях свт. Григория Богослова // Вестник Университета Дмитрия Пожарского. 2014. № 1 (1). С.244251; а также его статью «Иерархический строй Церкви в творениях свт. Григория Богослова» в сборнике «Nazianzena Rossica. Григорий Богослов: исследования и переводы» (в печати).

${ }^{74}$ Spataru D. Sacerdoti e diaconesse: la gerarchia ecclesiastica secondo i padri cappadoci. Bologna: Edizioni Studio Domenicano, 2007; Citrini T. Presbiterio e presbiteri. II. Nella fucina dei grandi padri (IV-V secolo). Milano: Ancora, 2011. P. 18-97. - Из русской дореволюционной традиции нельзя не отметить монографию, где автор использует тексты свт. Григория в основном как источник по критике епископата: Лебедев А. П. Духовенство древней Вселенской церкви. СПб.: Издательство Олега Абышко, 2006 (1-е изд.: М.: Изд. А. И. Снегиревой, 1896-1905 гг.).

75 В русской традиции это учебники пастырского богословия, которые часто содержат разделы с учением о пастырстве Святых Отцов. См., напр.: Иоанн (Маслов), схиархим. Лекции по пастырскому богословию. М.: Самшит, 2001. - В западной традиции отметим достаточно схожую по подходу книгу, где первый раздел посвящен «Апологии» свт. Григория (Purves A. Pastoral Theology in the Classical Tradition. London: Westminster John Knox Press, 2001. P.9-32). Эти тексты представляют достаточно подробный, но не очень критический анализ текста вне какой-либо исторической проблематики с ощутимыми дидактическими нотами.

${ }^{76}$ Beeley C.A. Gregory of Nazianzus on the Trinity and the Knowledge of God: In Your Light We Shall See Light. Oxford: Oxford University Press, 2008. См. также его статью практического характера, учитывающую материал свт. Григория: Beeley C. A. Theology and Pastoral Leadership // Anglican Theological Review. 2009. Vol. 91 (1). P. 11-30.

77 Beeley C. A. Gregory of Nazianzus on the Trinity and the Knowledge of God. P. 235-270. 
о фигуре богослова, христологии, пневматологии, триадологии. Это объясняется тем, что акцент в названных главах ставится на богословских аспектах учения свт. Григория о священстве. К.Били подчеркивает «пастырский характер тринитарной доктрины Григория и тринитарные формы пастырского служения» ${ }^{78}$, приводя в сноске тексты Э. Лаута, А. Стерк, С. Эльм и К. Рапп, что не лишено остроумия в указанном нами «полемическом» контексте.

Строя свой анализ фактически как комментарий «Апологии», К. Били раскрывает практически все темы, поднятые свт. Григорием, в удивительной полноте, показывая многогранность этого текста. Не рассматривая литературную форму и контексты Слов Назианзина, он указывает на огромное количество связей внутри корпуса свт. Григория, демонстрируя, каким образом его тексты дополняют друг друга. Также исследователь выделил вопрос о природе власти священника, указал на особую роль Писания как в становлении, так и в деятельности пастыря ${ }^{79}$, отметил его социальную деятельность на материале 14-го Слова о любви к бедным (см. выше в п. 8 о Демакопулосе), а также продемонстрировал, что, согласно свт. Григорию, именно правильная проповедь богословия Троицы (а не исполнение таинств) является главной задачей пастыря. Однако самое значимое достижение К. Били состоит в том, что на протяжении всего текста этой главы показано: сама возможность деятельности священника обосновывается через включение клира в икономию Христа, а вся эта деятельность происходит при действии Св. Духа.

Поскольку две другие работы специально концентрируются на этих аспектах, обратимся к ним. Докторская диссертация Д. Опперваля «Святой Дух в жизни и творениях Григория Назианзина» ${ }^{80}$ и монография Э. Хофера “Христос в жизни и учении Григория Назианзина» ${ }^{81}$ предлагают новый, принципиально несистемный подход в богословских исследованиях. Главный тезис обеих работ - богословие для свт. Григория было не догматической системой, а глубинным переживанием. Они показывают ходы мысли, самоощущение и саморепрезентацию, обусловленные христианским вероучением: личность Христа является образующей для творчества и мысли Богослова на всех уровнях, а Святой Дух действительно выступает главным актором в Церкви и в жизни Богослова.

Во введении к гл. 6 «Христообразное священство у Григория» ${ }^{82} Э$. Хофер вербализирует полемический контекст всей работы именно при обраще-

${ }^{78}$ Beeley C. A. Gregory of Nazianzus on the Trinity and the Knowledge of God. P. 236.

79 Эти и ряд перечисленных ниже аспектов замечательно раскрыты в статье: Fulford B. Gregory of Nazianzus and Biblical Interpretation // Re-Reading Gregory of Nazianzus / ed. by C. Beeley. Washington: Catholic University of America Press, 2012. P.31-48.

${ }^{80}$ Opperwall D. G. The Holy Spirit in the Life and Writings of Gregory of Nazianzus. PhD Thesis. Hamilton: McMaster University, 2012.

${ }^{81}$ Hofer A. Christ in the Life and Teaching of Gregory of Nazianzus. Oxford: Oxford University Press, 2013.

${ }^{82}$ Ibid. P. 196-225. 
нии к теме священства. Он выступает и против исследователей, действующих в рамках Dogmengischichte, поскольку они вообще «не видят» пастыря в своих штудиях, и против тех, кто, практически полностью игнорируя христианские предпосылки учения свт. Григория, рассматривает его тексты о священстве как реплику в философском платоническом дискурсе, причем упоминаются большинство из названных нами выше работ. Автор показывает богословские основания легитимации священства (как и К.Били на материале Or. 2.23-26), предшествующие в его понимании дискурсу о лидерстве и авторитете. Следуя своему наставлению, согласно которому священник должен учить словом и делом, свт. Григорий, «перелагая свою жизнь в учение, предлагает свой разум для очищения читателей» ${ }^{83}$, причем сущностным элементом в его автобиографии является христообразность. Кроме этого, он анализирует образ Христа в описаниях епископов, а также представление Назианзина о том, чему должен учить священник. Здесь, кроме уже встречавшейся нам социальной направленности проповеди (на материале дважды упомянутого 14-го Слова), мы видим сравнение девства и брака как двух путей жизни, причем в обеих частях Э. Хофер находит принципиальным значение образа Христа в риторике свт. Григория.

Д. Опперваль при описании действия Святого Духа в Церкви указывает на Его особую роль при рукоположении священника и проповеди, что представляется важным противовесом предшествующим исследованиям, сконцентрированным на позднеантичном контексте. Однако важнее то, что исследователь показал: «Григорий Назианзин видит себя христианским лидером, которого направляет Святой Дух» ${ }^{84}$, поскольку именно автобиографические тексты свт. Григория, где он репрезентирует себя в первую очередь как священника, позволяют увидеть во всем его наследии не «идеальные образы» пастырей, но весь путь становления и деятельность пастыря душ в многогранной сложности.

\section{1. Труды об автобиографии}

Внимание к автобиографическому материалу не случайно. Эта тема стала активно разрабатываться в последние десятилетия ${ }^{85}$. Если раньше автобиографические поэмы и слова служили в первую очередь источниками для реконструкции биографии святителя, то последние исследования предлагают новый взгляд на эти тексты, который я сформулировал в трех тезисах, объединяющих, как мне кажется, множество разных работ в цельное высказывание:

- после отъезда из Константинополя свт. Григорий не пребывал в покое от церковных дел, занимаясь литературными трудами

${ }^{83}$ Hofer A. Christ in the Life and Teaching of Gregory of Nazianzus. P. 199.

${ }^{84}$ Opperwall D. G. The Holy Spirit in the Life and Writings of Gregory of Nazianzus. P. 119.

85 Эта разработка присутствовала во многих рассмотренных нами работах, здесь же мы приведем несколько значимых, на наш взгляд, статей, часть из которых уже указывали выше. 
(этот штамп транслируется во многих общих работах о Богослове), но именно через свои тексты старался активно влиять на жизнь Церкви ${ }^{86}$;

- особое значение в этих текстах имеет автобиографический материал, использование которого было призвано служить усилению личного авторитета святителя ${ }^{87}$ (наряду с другими программными моментами - привлечением на свою сторону образа свт. Василия ${ }^{88}$, критикой епископата и т.д.);

- влияние этих текстов оказалось столь значительным, что говорить о церковно-политическом провале свт. Григория (другой распространенный штамп ${ }^{89}$ ) не приходится.

${ }^{86}$ Выше мы указывали статью: McLynn N.B. The Voice of Conscience: Gregory Nazianzen in Retirement. - См. также: Storin B. K. In a Silent Way: Asceticism and Literature in the Rehabilitation of Gregory of Nazianzus // Journal of Early Christian Studies. 2011. Vol. 19. P. 226-257.

${ }^{87}$ См., напр.: Bernardi J. Trois autobiographies de saint Gregoire de Nazianze; McLynn N. A Self-Made Holy Man: The Case of Gregory Nazianzen // Journal of Early Christian Studies. 1998. No. 6. P.463-483; Dam R.V. Self-representation in the will of Gregory of Nazianzus // The Journal of Theological Studies. 1995. No. 46. P.118-148; McGuckin J. Autobiography as Apologia in St. Gregory of Nazianzus // Studia patristica. 2001. No. 37. P.160-177; Gautier F. La retraite et le sacerdoce chez Grégoire de Nazianze. P.214-241 (ч. 2, гл. 3); Papaioannou S. Gregory and the Constraint of Sameness // Gregory of Nazianzus: Images and Reflections / eds J.Børtnes, T.Hägg. Copenhagen: Museum Tusculanum Press, 2006. P.29-81; Rebillard S.A. Historiography as Devotion: Poemata de seipso // Re-Reading Gregory of Nazianzus / ed. by C. Beeley. Washington: Catholic University of America Press, 2012. P. 125-142; Elm S. Apology as Autobiography - An Episcopal Genre? Emperor Julian, Gregory of Nazianzus, Augustine of Hippo // Spätantike Konzeptionen von Literatur / ed. by J.Stenger. 2015. No. 2. P.33-49; Storin B.K. Autohagiobiography: Gregory of Nazianzus among His Biographers // Studies in Late Antiquity. 2017. No. 3. P.254-281; Bady G. La vie comme "Écriture" chez Grégoire de Nazianze // Grégoire de Nazianze, le passeur de mondes, Actes de la neuvième Petite Journée de patristique (18 mars 2017, Saintes) / éd. P. -G. Delage. Royan: CaritasPatrum, 2017. P.2541; Kuhn-Treichel T. A Man Completely Devoid of Falsehood? Creating Credibility in Gregory Nazianzen's Autobiographical Poems // Vigiliae Christianae. 2020. Vol. 74, no. 3. P. 289-302.

${ }^{88}$ См., напр.: McLynn N. Gregory Nazianzen's Basil: The Literary Construction of a Christian Friendship // Studia Patristica. 2001. No. 37. P. 178-193; Norris F. W. Your honor, my reputation: St. Gregory of Nazianzus's funeral oration on St. Basil the Great // Greek Biography and Panegyric in Late Antiquity / eds T. Hägg, Ph. Rousseau. Berkley: University of California Press, 2000. P. 140-159; Konstan D. How to Praise a Friend: St. Gregory of Nazianzus's funeral oration for St. Basil the Great // Ibid. P. 160-179; Børtnes J. Eros Transformed: Same-Sex Love and Divine Desire // Ibid. P. 180-193; Storin B. K.: 1) The Letter Collection of Gregory of Nazianzus // Late Antique Letter Collection: a Critical Introduction and Reference Guide / eds C. Sogno, B. K. Storin, E. J. Watts. Oakland: University of California Press, 2016. P. 81-101; 2) Self-Portrait in Three Colors: Gregory of Nazianzus's Epistolary Autobiography. Oakland: University of California Press, 2019.

89 «Личность идеальная и возвышенная, он не был создан для практической деятельности, не обладая ни силой воли, ни энергией, ни практическим умом и хладнокровием, качествами, столь необходимыми в это ужасное для Церкви время» (Барсов Н. И. Святой Григорий Богослов как проповедник // Христианское чтение. 1886. № 2. С. 322). То же самое транслируется и в современных работах. См., напр.: Hauschild W. D., Drecoll V. H. Lehrbuch der Kirchen- und Dogmengeschichte: Alte Kirche und Mittelalter. München: Gütersloh, 2016. 
Общий пафос этих работ - автобиографии свт. Григория являются чем-то большим, чем простым описанием своей жизни, - без сомнения, очень важен для понимания наследия Богослова в целом и темы священства в нем в частности. Однако акцент на апологетической составляющей этих текстов (которую логично ожидать от любой автобиографии) кажется отчасти избыточным, а иногда недостаточно критическим и загораживающим другие, в первую очередь педагогические, аспекты этих текстов. Особенно это сказывается на понимании ${ }^{90}$ «Апологии», восприятие которой как «автоагиографии» мешает исследователям корректно ее интерпретировать ${ }^{91}$.

\section{Заключение}

Подводя итоги, укажем два направления в исследованиях темы священства, которые, по нашему мнению, достойны дальнейшего развития и нуждаются в обобщении.

Во-первых, перспективным видится подход, реализуемый в работах, направленных на анализ общих черт всего корпуса текстов свт. Григория (Эльм, Хофер, Опперваль), а не на реконструкцию системы мысли, за ним стоящей. Особое значение здесь имеет тезис Ж.Бернарди о том, что свт. Григорий сам формировал единый корпус своих Слов, поскольку при такой оптике мы реконструируем объективно наличествующую логику, в соответствии с которой дошедшие до нас тексты были отобраны и сохранены святителем. Конечно, данная гипотеза требует серьезных усилий по верификации и разработке, однако и без этого утверждения поиск интегрального подхода ко всему наследию свт. Григория необходим, а тема священства кажется здесь принципиальной.

Во-вторых, исходя из того, что исследователи предлагают рассматривать тему священства в разных, иногда противопоставленных друг другу контекстах, представляется необходимым изучать «Апологию» как сложный интертекст, сочетающий разные элементы предшествующих традиций (ранее исследователи старались выделить один как ключевой). Соответственно, только выделив все контексты, привлекаемые свт. Григорием при описании пастыря, и проанализировав материал, им используемый, можно будет увидеть образ священника, им сформированный. Думается, что метафора мозаики, примененная Лохбруннером при анализе «Апологии», отвечает природе текста и показывает верный подход к нему.

\footnotetext{
S. 100. Против этого историко-событийного подхода, не учитывающего историю мысли, во многом выступает С. Эльм (Elm S. Sons of Hellenism. P. 5).

${ }^{90}$ Elm S. Apology as Autobiography. P.41. - См. также: McLynn. Self-Made Holy Man. P. 468-470.

${ }^{91}$ Более подробное обоснование этого тезиса см. в нашей статье «Жанровые и структурные особенности “Апологии” свт. Григория Богослова» в сборнике «Nazianzena Rossica. Григорий Богослов: исследования и переводы» (в печати).
} 
Добавим, что исследования темы священства в творениях свт. Григория не прекращаются ${ }^{92}$.

Статья поступила в редакцию 16 февраля 2021 г.

Статья рекомендована к печати 26 февраля 2021 г.

Информация об авторе:

Антонов Николай Константинович - приглашенный сотрудник

Лаборатории исследований церковных институций; nickforgo@gmail.com

\title{
A review of research literature on the topic of the priesthood in the works of st. Gregory the Theologian*
}

\author{
N. K. Antonov \\ St. Tikhon's Orthodox University for the Humanities, \\ 6/1, Likhov per., Moscow, 127051, Russian Federation
}

For citation: Antonov N. K. A review of research literature on the topic of the priesthood in the works of st. Gregory the Theologian. Issues of Theology, 2021, vol. 3, no. 2, pp. 177-208. https://doi.org/10.21638/spbu28.2021.204 (In Russian)

The article examines the tradition of research on the topic of the priesthood in the legacy of St. Gregory the Theologian from the $19^{\text {th }}$ century to 2020 . The review includes general monographs on both the formation of the episcopate in Late Antiquity and specifically the legacy of Nazianzen, dissertations, publications in periodicals, dictionaries and encyclopedias on this topic, as well as on a wide range of related topics, key publications and translations of the Apology on his Flight - St. Gregory's central text on the priesthood - in English, Russian, German, French and Italian. The following periodization of historiography is proposed: the early period ( $19^{\text {th }}-$ middle of $20^{\text {th }}$ centuries), theological studies of the Apology in the 50s-70s, studies and publications by J. Bernardi, the "new wave" of the 1990s and its development in the $21^{\text {st }}$ century. In the last period, three main trends are identified: the Theologian's texts on the priesthood are considered in the context of: the development of the image of a monk-bishop in Late Antiquity; platonic political philosophy; Gregory's main theological concepts. The importance of research on other aspects of Gregory's work is shown especially the categories $\theta \varepsilon \omega \rho i \alpha / \pi \rho \tilde{a} \xi_{\iota \varsigma}$ and his autobiographical texts. Two lines of further research are proposed as the

${ }^{92}$ См., напр.: Phillips S. Fit or unfit for priesthood? Priestly ministry according to the writings of Gregory of Nazianzus // Logos. 2001. Vol.41. P.333-362; Goad K. Why pastors should flee the ministry: a meditation from the pastoral theology of Gregory of Nazianzus // Churchman. 2010. Vol.124 (2). P.105-126; MacDougall B. Callimachus and the Bishops: Gregory of Nazianzus's Second Oration // Journal of Late Antiquity. 2016. Vol.9. P.171-194; Антонов Н.К. Категории становления священника в учении святителя Григория Богослова // Христианское чтение. 2017. № 2. С.98-111; Немыченков В. И. Структура евхаристической жертвы и жертвоприношение иерея по учению святителя Григория Богослова // Развитие личности. 2017. №. 2. С.94-112; Goligher C. Trinitarian Orthodoxy and Pastoral Ministry: Reflections on Being Nicene in the Twenty-First Century // Puritan Reformed Journal. 2018. Vol. 10 (2). P. 243-255.

* The reported study was funded by RFBR, project number 20-311-90020. 
most promising: intertextual analysis of the Apology and integral analysis of the entire legacy of St. Gregory through the prism of the priesthood theme.

Keywords: St. Gregory the Theologian, Gregory of Nazianzus, priesthood, historiography, Late Antiquity, autobiography, theology.

\section{References}

[Anonim.] (1894) "Consecration of St. Gregory the Theologian in presbyter", in Kishinevskie eparkhial'nye vedomosti, no. 2, pp. 31-42. (In Russian)

Agapit, arkhim. (1869) The Life of St. Gregory the Theologian, archpriest of Constantinople, and his pastoral activity. St. Petersburg, Strannik Publ. (In Russian)

Antonov N. K. (2017) "Categories of the Formation of Clergy in the Teachings of St. Gregory the Theologian", in Khristianskoe chtenie, no. 2, pp. 98-111. (In Russian)

Bady G. (2017) "La vie comme 'Écriture' chez Grégoire de Nazianze”, in Grégoire de Nazianze, le passeur de mondes, Actes de la neuvième Petite Journée de patristique (18 mars 2017). Éd P.-G. Delage, pp. 25-41. Royan, CaritasPatrum.

Barsov N.I. (1886) "St. Gregory the Theologian as Preacher", in Khristianskoe chtenie, no. 2, pp. 316-361. (In Russian)

Beeley C. A. (2008) Gregory of Nazianzus on the Trinity and the Knowledge of God: In Your Light We Shall See Light. Oxford, Oxford University Press.

Beeley C.A. (2009) "Theology and Pastoral Leadership", in Anglican Theological Review, vol. 91 (1), pp. 11-30.

Bellini E. (1963) "La predicazione in San Gregorio Nazianzeno (a proposito di Oratio II 35, 50)", in La Scuola Cattolica, vol. 9, pp. 496-506.

Bellini E. (1970) La chiesa nel mistero della salvessa in San Gregorio Nazenzeno. Venegono Inferiore, Seminario Arcivescovile Di Milano.

Bellini E. (1971) "La figura del Pastore d'anime in san Gregorio Nazianzeno", in La Scuola Cattolica, vol. 99, pp. 261-296.

Benoit A. (1876) Saint Grégoire de Nazianze. Sa vie, ses oeuvres, et son époque. Marseille. (Reprint: (1973) New York, Hildesheim; Olms Publ.).

Bernardi J. (1968) La prédication des Pères cappadociens: Le prédicateur et son auditoire. Paris, Publications de la Faculté des Lettres et Sciences Humaines de l'Université de Montpellier.

Bernardi J. (1990) "Un regard sur la vie Étudiante à Athènes au milieu du IVe s. après J.-C.", in Revue des Études Grecques, vol. 103, pp. 79-94.

Bernardi J. (1993) “Trois autobiographies de saint Gregoire de Nazianze”, in L'invention de l'autobiographie: d'Hésiode à Saint Augustin. Eds M. F. Baslez, P. Hoffmann, L. Pernot, pp. 155165. Paris, Rue d'Ulm.

Bernardi J. (1995) Saint Grégoire de Nazianze. Le Théologien et son temps (330-390). Paris, Les Éditions du Cerf.

Bernardi J., ed. (1978) Gregoire de Nazianze. Discourse 1-3. Paris, Les Éditions du Cerf Publ. (Sources Chrétiennes. Vol.247).

Biriukov D. S. (2007) "Faith-language: Julian and St. Gregory Nazianzus", in Imperator Iulian: sochineniia. Ed. by D. S. Biriukov, pp. 55-90. St. Petersburg, Izdatel'stvo Sankt-Peterburgskogo universiteta Publ. (In Russian)

Borisovskij P. (1894) "Dogmatic Foundations of Christian Morality according to the Works of St. Gregory the Theologian", in Vera i razum, no. 7, pp. 443-457; no. 8, pp. 509-525. (In Russian)

Borisovskij P. (1898) "The thoughts of St. Gregory the Theologian on the Christian life of solitary contemplation and Social activity", in Vera i razum, no. 6, pp. 349-374; no. 8, pp. 491-520. (In Russian) 
Børtnes J. (2000) “Eros Transformed: Same-Sex Love and Divine Desire”, in Greek Biography and Panegyric in Late Antiquity. Eds T. Hägg, Ph. Rousseau, pp. 180-193. Berkley, University of California Press.

Brown P. (2002) Poverty and Leadership in the Later Roman Empire. Hanover, University Press of New England.

Bruni A. M. (2010) The Byzantine Tradition and the Old Slavonic Translation of the Words of Gregory of Nazianz. Moscow, Institut vseobshchei istorii RAN Publ. (In Russian)

Chetyrkin F. V. (1895) St. Gregory the Theologian. St. Petersburg, Tipografiia F. Eleonskago i K ${ }^{\circ}$ Publ. (In Russian)

Christensen M.J., Wittung J.A., eds. (2007) Partakers of the Divine Nature: The History and Development of Deification in the Christian Traditions. Madison, Baker Academic Publ.

Citrini T. (2011) Presbiterio e presbiteri. II. Nella fucina dei grandi padri (IV-V secolo). Milano, Ancora Publ.

Daley B.E. (1999) "Building a New City: The Cappadocian Fathers and the Rhetoric of Philanthropy", in Journal of Early Christian Studies, no. 7, pp. 431-461.

Daley B. E. (2006) Gregory of Nazianzus. Early Church Fathers. London, Taylor \& Francis Publ.

Dam R. V. (1995) "Self-representation in the will of Gregory of Nazianzus", in The Journal of Theological Studies, no. 46, pp. 118-148.

Demacopoulos G. E. (2006) Five Models of Spiritual Direction in the Early Church. Notre Dame, University of Notre Dame Press.

Demoen K. (1997) "Acteurs de pantomimes, trafiquants du Christ, flatteurs de femmes... Les évêques dans les poèmes autobiographiques de Grégoire de Nazianze", in Vescovi e pastore in epoca Teodosiana. In 2 vols, vol. II, pp. 287-298. Rome, Institutum Patristicum Augustinianum.

Dubuisson M., Macé C. (2002) "La place des versions anciennes dans l'histoire du texte de Grégoire de Nazianze. Le cas du Discours 2", in Orientalia christiana periodica, vol. 68, pp. 287-340.

Dubuisson M., Macé C. (2003) "Lapport des traductions anciennes a l'histoire du texte de Grégoire de Nazianze. Application au Discours 2", in Orientalia christiana periodica, vol. 69, pp. 287-340.

Dorries H. (1973) "Erneuerung des kirchlichen Amts im vierten Jahrhundert: Die Schrift De sacerdotio des Johannes Chrysostomus und ihre Vorlage, die Oratio de fuga sua des Gregor von Nazianz", in Bleibendes im Wandel der Kirchengeschichte. Hrsg. B. Moeller, G. Ruhbach, pp. 1-46. Tübingen, Mohr.

Elm S. (1994) "Virgins of God": The Making of Asceticism in Late Antiquity. Oxford, Oxford University Press.

Elm S. (1999) "Inventing the Father of the Church: Gregory of Nazianzus' 'Farewell to the Bishops' (Or. 42) in its Historical Context", in Vita Religiosa im Mittelalter. Eds F. Felten, N. Jaspert, pp. 3-20. Berlin, Duncker \& Humblot Publ.

Elm S. (2000) "A Programmatic Life: Gregory of Nazianzus' Orations 42 and 43 and the Constantinopolitan Elites", in Arethusa, vol. 33, no. 3, pp. 411-427.

Elm S. (2000) "The diagnostic gaze. Gregory of Nazianzus' theory of orthodox priesthood in his Orations 6 De pace and 2 Apologia de fuga sua", in Orthodoxy, Christianity, History. Eds S. Elm, E. Rebillard, A. Romano, pp. 83-100. Roma, École Française de Rome.

Elm S. (2001) "Orthodoxy and the Philosophical Life: Julian and Gregory of Nazianzus", in Studia Patristica, vol. 37, pp. 69-85.

Elm S. (2003) "Hellenism and historiography: Gregory of Nazianzus and Julian in dialogue", in Journal of Medieval and Early Modern Studies, vol. 33, pp. 493-515.

Elm S. (2003) "Historiographic Identities: Julian, Gregory of Nazianzus, and the Forging of Orthodoxy", in Zeitschrift für antikes Christentum, vol. 7, S. 249-266.

Elm S. (2012) Sons of Hellenism, fathers of the church: Emperor Julian, Gregory of Nazianzus, and the vision of Rome. Berkley, LA, London, University of California Press. 
Elm S. (2013) "Priest and Prophet: Gregory of Nazianzus's Concept of Christian Leadership as Theosis", in Priests and Prophets among Pagans, Jews and Christians. Eds B. Dignas, R. Parker, G. G. Stroumsa, pp. 162-184. Leuven, Paris, Walpole, Peeters Publ.

Elm S. (2015) "Apology as Autobiography - An Episcopal Genre? Emperor Julian, Gregory of Nazianzus, Augustine of Hippo" in Spätantike Konzeptionen von Literatur. Ed. by J. Stenger, no. 2, pp. 33-49.

Elm S. (2015) "Gregory of Nazianzus: mediation between individual and community", in Group Identity and Religious Individuality in Late Antiquity. Ed. by E. Rebillard, pp. 89-107. Washington, Catholic University of America Press.

Engelbrecht A., ed., transl. (1910) Tyrannii Rufíni orationum Gregorii Nazianzeni novem interpretation. Wien, Leipzig, Vindobonae, F. Tempsky Publ. (Corpus scriptorum ecclesiasticorum latinorum. Vol. 46).

Fiedrowicz M., Barthold C., eds. (2019) Gregor von Nazianz. Priestertum und Bischofsamt: Apologia de fuga sua (Oratio 2). Fohren-Linden, Carthusianus Verlag.

Fleury E. (1930) Saint Gregoire de Nazianze et son temps: hellénisme et christianisme. Paris, Beauchesne.

Fulford B. (2012) "Gregory of Nazianzus and Biblical Interpretation", in Re-Reading Gregory of Nazianzus. Ed. by C. Beeley, pp. 31-48. Washington, Catholic University of America Press.

Gallay P. (1943) La vie de saint Grégoire de Nazianze. Lyon, E. Vitte Publ.

Gallay P. (1964) Gregor von Nazianz. Stuttgart, Schwabenverl.

Gallo P. (1985) "Apologeticus de fuga" di San Gregorio Nazianzeno: studio sul sacerdozio e traduzione in italiano. Roma, Pontificia Universitas Lateranense.

Gautier F. (2002) La retraite et le sacerdoce chez Grégoire de Nazianze. Turnhout, Brepols Publ.

Goad K. (2010) "Why pastors should flee the ministry: a meditation from the pastoral theology of Gregory of Nazianzus", in Churchman, vol. 124 (2), pp. 105-126.

Goligher C. (2018) "Trinitarian Orthodoxy and Pastoral Ministry: Reflections on Being Nicene in the Twenty-First Century", in Puritan Reformed Journal, vol. 10 (2), pp. 243-255.

Gonçalo Alves de Sousa P. (1974) "El sacerdocio permanente en la 'Oratio II, Apologetica' de San Gregorio Nacianceno", in Escritos sobre el carácter sacerdotal. Ed. by J. Ibánez. Burgos, Aldecoa, pp. 25-41.

Gottwald R. (1906) De Gregorio Nazianzeno platonico. Vratislaviae, H. Fleischmann Publ.

Griffith S. (2006) "Iatros and Medicus: The Physician in Gregory Nazianzen and Augustine", in Studia Patristica, no. 41, pp. 319-325.

Grigorij (Vasilev), arkhim. (1916) St. Gregory the Theologian as a shepherd and teacher of pastoral care. Sergiev Posad, Tipografiia Sviato-Troitskoi Sergievoi Lavry Publ. (In Russian)

Gwynn D. M. (2012) "Episcopal Leadership", in The Oxford Handbook of Late Antiquity. Ed. by S. F. Johnson. Oxford, Oxford University Press.

Harl M. (1967) "Les trois quarantaines de la vie de Moïse, schéma idéal de la vie du moineévêque chez les Pères Cappadociens", in Revue des Études Grecques, vol. 80, pp. 407-412.

Hartless B. (2014) "The art of arts and the science of sciences": the cure of the soul and the leadership role of the clergy. $\mathrm{PhD}$ thesis. London, King's College.

Hartmann C. (2004) "Aus einem Funken das himmlische Licht - Gedanken zur Ekklesiologie Gregors von Nazianz", in Vaeter der Kirche. Ekklesiales Denken von den Anfaengen bis in die Neuzeiten. Hrsg. J. Arnold, R. Berndt, R. Stammberger, S.217-239. Padeborn, Muenchen, Wien, Zuerich, Ferdinand Schöningh Publ.

Hauschild W.D., Drecoll V.H. (2016) Lehrbuch der Kirchen-und Dogmengeschichte: Alte Kirche und Mittelalter. München, Gütersloh Publ.

Hofer A. (2011) “The Reordering of Relationships in John Chrysostom's 'De sacerdotio"'. Augustinianum, vol. 51 (2), pp. 451-471.

Hofer A. (2013) Christ in the Life and Teaching of Gregory of Nazianzus. Oxford, Oxford University Press. 
Honigsberg A. E. (2006) "A City by Any Other Name...? Gregory of Nazianzus' Constantinople”, in Studia Patristica, vol. 41, pp. 357-362.

Hornung C. (2020) Monachus et sacerdos. Asketische Konzeptualisierungen des Klerus im antiken Christentum. Leiden, Boston, Brill Publ.

Iang F. M. (2013) From Nicaea to Chalcedon: An Introduction to Greek Patristic Literature and its Historical Context. Rus. ed. Moscow, Pravoslavnyi Sviato-Tikhonovskii gumanitarnyi universitet Publ. (In Russian)

Ilarion (Alfeev), ierom. (1998) The Life and Teachings of St. Gregory the Theologian. Moscow, Izdatel'stvo Sretenskogo monastyria Publ. (In Russian)

Ioann (Maslov), skhiarkhim. (2001) Lectures on Pastoral Theology. Moscow, Samshit Publ. (In Russian)

Jouassard G. (1959) "Pour une étude du sacerdoce au temps des Peres", in La tradition sacerdotale, pp. 109-125. Le Puy, X. Mappus Publ.

K. S. (1869) "Saint Gregory of Nazianzus as a denouncer of unworthy pastors", in Trudy Kievskoi dukhovnoi akademii, no. 4, pp. 3-13. (In Russian)

Kertsch M. (1974) “Gregor von Nazianz' Stellung zu 'Theoria' und 'Praxis' aus der Sicht seiner Reden”, in Byzantion, no. 44, pp. 282-289.

Konstan D. (2000) "How to Praise a Friend: St. Gregory of Nazianzus's funeral oration for St. Basil the Great", in Greek Biography and Panegyric in Late Antiquity. Eds T. Hägg, Ph. Rousseau, pp. 160-179. Berkley, University of California Press.

Kruglov A. V. (1899) St. Gregory the Theologian: An Essay on Life and Work. Moscow, Tipogragiia I. N. Kushnereva i Ko Publ. (In Russian)

Kuhn-Treichel T. (2020) "A Man Completely Devoid of Falsehood? Creating Credibility in Gregory Nazianzen's Autobiographical Poems", in Vigiliae Christianae, vol. 74, no. 3, pp. 289-302.

Lebedev A.P. (2006) Clergy of the ancient universal church. St. Petersburg, Izdatel'stvo Olega Abyshko Publ. (In Russian)

Limberis V. (2000) “'Religion' as the cipher for identity: the cases of emperor Julian, Libanius, and Gregory Nazianzus", in Harvard Theological Review, vol. 93, no. 4, pp. 373-400.

Lizzi Testa R. (1987) Il potere episcopale nell'Oriente romano. Roma, Filologia e critica Publ.

Lochbrunner M. (1993) Über das Priestertum: historische und systematische Untersuchung zum Priesterbild des Johannes Chrysostomus. Bonn, Borengässer Publ.

Louth A. (1997) "St. Gregory Nazianzen on Bishops and the Episcopate", in Vescovi e pastore in epoca Teodosiana. In 2 vols, vol. II, pp. 281-285. Rome, Institutum Patristicum Augustinianum.

MacDougall B. (2016) "Callimachus and the Bishops: Gregory of Nazianzus's Second Oration", in Journal of Late Antiquity, vol. 9, pp. 171-194.

Malingrey A.-M., ed. (1980) Jean Chrysostome. Sur le sacerdoce (Dialogue et Homélie). Paris, Les Éditions du Cerf. (Sources Chrétiennes. Vol.272).

Maslov B. (2012) "Oikeiōsis pros theon: Gregory of Nazianzus and the heteronomous subject of Eastern Christian penance", in Journal of Ancient Christianity, no. 16 (2), pp. 311-343.

Maslov B. (2012) "The Limits of Platonism: Gregory of Nazianzus and the Invention of theōsis", in Greek, Roman, and Byzantine Studies, no. 52, pp. 440-468.

Matz B. J. (2004) "Philippians 2:7 as Pastoral Example in Gregory Nazianzen's Oration 12", in Greek orthodox theological review, vol. 49 (3-4), pp. 279-290.

Matz B. J. (2012) "Deciphering a Recipe for Biblical Preaching in Oration 14", in Re-Reading Gregory of Nazianzus. Ed. by C. Beeley, pp. 49-66. Washington, Catholic University of America Press.

Matz B. J. (2016) Gregory of Nazianzus. Michigan, Baker Books.

Mayer W. (2015) “The persistence in Late Antiquity of medico-philosophical psychic therapy", in Journal of Late Antiquity, vol. 8, no. 2, pp. 337-351.

McGuckin J. (2001) "Autobiography as Apologia in St. Gregory of Nazianzus", in Studia patristica, no. 37, pp. 160-177. 
McGuckin J. (2001) Saint Gregory of Nazianzus: An Intellectual Biography. New York, St. Vladimir's Seminary Press.

McGuckin J. (2015) "St. Gregory of Nazianzus on the Love of the Poor (Oration 14)", in The Ecumenical Legacy of Cappadocians. Ed. by N. Dumitrascu, pp. 139-157. New York, Palgrave Macmillan Publ.

McLynn N. (1997) "The Voice of Conscience: Gregory Nazianzen in Retirement", in Vescovi e pastore in epoca Teodosiana. In 2 vols, vol. II, pp. 299-308. Rome, Institutum Patristicum Augustinianum.

McLynn N. (1998) "A Self-Made Holy Man: The Case of Gregory Nazianzen" in Journal of Early Christian Studies, no. 6, pp. 463-483.

McLynn N. (2001) "Gregory Nazianzen's Basil: The Literary Construction of a Christian Friendship", in Studia Patristica, no. 37, pp. 178-193.

McLynn N. (2001) "Gregory Nazianzen's Basil: The Literary Construction of a Christian Friendship" in Studia Patristica, vol. 37, pp. 178-193.

Menn. (1904) "Zur Pastoraltheologie Gregors von Nazianz", in International Theological Review, vol. 12, pp. 427-440.

Migne J.-P., ed. (1862) Gregorius Nazianzenus. Opera quae existant omnia. D’Amboise, 1862 (Patrologia Graeca. Vol.35).

Molac P. (2004) "Des sources nazianzéennes au discours sur le sacerdoce de Saint Jean Chrysostome", in Bulletin de littérature ecclésiastique, vol. 105, no. 2, pp. 169-174.

Moreschini C. (1997) Filosofia e letteratura in Gregorio di Nazianzo. Milano, Vita e pensiero.

Moreschini C., Sani C., Vincelli M., eds. (2000) Gregorio di Nazianzo (san). Tutte le orazioni. Milano, Città nuova Publ.

Moreskini K. (2011) The History of Patristic Philosophy. Rus. ed. Moscow, Greko-latinskii kabinet Iu. A. Shichalina Publ. (In Russian)

Nemychenkov V. I. (2017) “The structure of the Eucharistic Sacrifice and the Priest's Sacrifice according to the teachings of St. Gregory the Theologian", in Razvitie lichnosti, no. 2, pp. 94112. (In Russian)

Norris F. W. (2000) "Your honor, my reputation: St. Gregory of Nazianzus's funeral oration on St. Basil the Great", in Greek Biography and Panegyric in Late Antiquity. Eds T. Hägg, Ph. Rousseau, pp. 140-159. Berkley, University of California Press.

O’Meara D. J. (2003) Platonopolis: Platonic Political Philosophy in Late Antiquity. Oxford, Oxford University Press.

Oosthout H. (1989) "La vie contemplative: vie d'ascète ou vie de théologien? Purification et recherche de Dieu chez Athanase d'Alexandrie et Grégoire de Nazianze", in Fructus Centesimus. Ed. by A. R. Bastiaensen, pp. 258-267. Turnhout, Brepols Publ.

Opperwall D. G. (2012) The Holy Spirit in the Life and Writings of Gregory of Nazianzus. PhD Thesis. Hamilton, McMaster University.

Papaioannou S. (2006) "Gregory and the Constraint of Sameness", in Gregory of Nazianzus: Images and Reflections. Eds J. Børtnes, T. Hägg, pp. 29-81. Copenhagen, Museum Tusculanum Press.

Patrucco M.F. (2005) "Bishops and Monks in Late Antique Society", in Zeitschrift für Antikes Christentum, no. 8, pp. 332-345.

Phillips S. (2001) "Fit or unfit for priesthood? Priestly ministry according to the writings of Gregory of Nazianzus", in Logos, vol. 41, pp. 333-362.

Pinault H. (1925) Le platonisme de St. Grégoire de Nazianze. La Roche-Sur-Yon, G. Romain Publ. Plagnieux J. St. (1952) Grégoire de Nazianze théologien. Paris, Franciscaines Publ.

Popov I. V. (1903) Gregory the Theologian, in Pravoslavnaia bogoslovskaia entsiklopediia, vol. 4, pp. 615-626. (In Russian)

Porfirii (Popov), arkhim. (1864) “The Life of St. Gregory the Theologian”, in Trudy Kievskoi dukhovnoi akademii, no. 4, pp. 400-430. (In Russian) 
Portmann F. X. (1954) Die göttliche Paidagogia bei Gregor von Nazianz: eine dogmengeschichtliche Studie. Ottilien, St. Ottilien Eos Verlag.

Pouchet J.-R. (1997) "Athanase d'Alexandrie, modele de l'évêque, selon Grégoire de Nazianze, Discours 21", in Vescovi e pastore in epoca Teodosiana. In 2 vols, vol. II, pp. 347-358. Rome, Institutum Patristicum Augustinianum.

Pouliot J. (1997) La paternité spirituelle du sacerdoce chez saint Ambroise de Milan, saint Grégoire de Nazianze et saint Jean Chrysostome. Master Thesis. Québec, Université Laval.

Purves A. (2001) Pastoral Theology in the Classical Tradition. London, Westminster John Knox Press.

Quasten J. (1986) Patrology. In 4 vols, vol. III. Westminster, Utrecht Spectrum.

Rapp C. (1998) "Comparison, Paradigm and the Case of Moses in Panegyric and Hagiography", in The Propaganda of Power: the role of panegyric in late antiquity. Ed. by M. Whitbe, pp. 277-298. Leiden, Boston, Köln, Brill Publ.

Rapp C. (2005) Holy Bishops in Late Antiquity. Berkley, University of California Press.

Rebillard S. A. (2012) "Historiography as Devotion: Poemata de seipso", in Re-Reading Gregory of Nazianzus. Ed. by C. Beeley, pp. 125-142. Washington, Catholic University of America Press.

Rousse J. (1964) “Saint Grégoire de Nazianze”, in Dictionaire de Spiritualité, vol. VI, pp. 932-971. Paris, Beauchesne.

Rousseau P., Papoutsakis M., eds. (2009) Transformations of Late Antiquity: Essays for Peter Brown. London, Routledge.

Ruether R. R. (1969) Gregory of Nazianzus. Rhetor and Philosopher. Oxford, Clarendon Press.

Russel N. (2004) The Doctrine of Deification in the Greek Patristic Tradition. Oxford, Oxford University Press.

Sadov F. (1888) "Pastoral Instructions of St. Gregory the Theologian", in Vera i razum, no. 1 (2), pp. 674-703. (In Russian)

Savramis D. (1968) Die soziale Stellung des Priesters in Griechenland. Leiden, Brill Archive Publ.

Sergeenko A., prot. (1956) "St. Gregory the Theologian on pastoral ministry", in Zhurnal Moskovskoi patriarkhii, vol. 12, pp. 52-56. (In Russian)

Serra M. (1995) "La caritá pastorale in San Gregorio Nazianzeno", in Orientalia Christiana Periodica, vol. 21, pp. 337-374.

Shevchuk M., priest. (1965) The Teachings of Saints Gregory the Theologian and John Chrysostom on the Height of Pastoral Ministry. PhD Thesis in Theology. Zagorsk, Moskovskaia dukhovnaia akademiia. (In Russian)

Sparacio P.F. (1997) From earth to heaven: an understanding of and vision for ordained ministry as guided by Gregory Nazianzus' Flight to Pontus and further grounded in the Fathers of the Church. PhD Diss. Drew University Publ.

Spataru D. (2007) Sacerdoti e diaconesse: la gerarchia ecclesiastica secondo i padri cappadoci. Bologna, Edizioni Studio Domenicano.

Špidlík T. (1971) "La theoria et praxis chez Grégoire de Nazianze", in Studia psatristica, vol. 14, pp. 358-364.

Špidlík T. (1971) Grégoire de Nazianze: introduction à létude de sa doctrine spirituelle. Roma, Orientalia Christiana Analecta Publ.

Sterk A. (1998) "On Basil, Moses, and the Model Bishop: The Cappadocian Legacy of Leadership", in Church History, vol. 67, pp. 227-253.

Sterk A. (2004) Renouncing the World, yet Leading the Church: The Monk-Bishop in Late Antiquity. Cambridge, Harvard University Press.

Storin B. K. (2011) "In a Silent Way: Asceticism and Literature in the Rehabilitation of Gregory of Nazianzus", in Journal of Early Christian Studies, vol. 19, pp. 226-257.

Storin B. K. (2016) "The Letter Collection of Gregory of Nazianzus", in Late Antique Letter Collection: a Critical Introduction and Reference Guide. Eds C. Sogno, B. K. Storin, E. J. Watts, pp. 81-101. Oakland, University of California Press. 
Storin B.K. (2017) "Autohagiobiography: Gregory of Nazianzus among His Biographers", in Studies in Late Antiquity, no. 3, pp. 254-281.

Storin B. K. (2019) Self-Portrait in Three Colors: Gregory of Nazianzus's Epistolary Autobiography. Oakland, University of California Press.

Szymusiak J.M. (1966) "Amour de la solitude et vie dans le monde à l'école de St. Grégoire de Nazianze", in La vie spirituelle, vol. 114, pp. 129-160.

Trisoglio F. (1996) Gregorio di Nazianzo il teologo. Milano, Vita e penserio Publ.

Troitskij I. E. (1863) "Last Years of St. Gregory the Theologian", in Khristianskoe chtenie, vol. 2 (6), pp. 147-193. (In Russian)

Ullmann C. (1825) Gregor von Nazianz, der Theologe. Darmstadt, Verlag von Carl Wilhelm Leske.

Van Hoof L., Nesselrath H. G. (2014) "The reception of Libanius: from Pagan friend of Julian to (almost) Christian Saint and back", in Libanius: a critical introduction, pp. 160-183. New York, Cambridge University Press.

Villegas N. G. (1997) "La corte de Constantinopla y su Obispo. A propósito de la Or. 36 de Gregorio de Nacianzo", in Vescovi e pastore in epoca Teodosiana. In 2 vols, vol. II, pp. 359-370. Rome, Institutum Patristicum Augustinianum.

Viscanti L., ed. (1987) Gregorio Nazianzeno. Fuga e autobiografia. Roma, Città nuova.

Volk J. (1895) "Die Schutzrede des Gregor von Nazianz und die schrift über das Priesterums von Joh. Chrysostomus", in Zeitschrift für praktische Theologie, Bd. 17, S. 56-63.

Von Campenhausen H. (1994) Griechische Kirchenväter. Stuttgart, Kohlhammer Verlag.

Wagner M. (1945) Rufinus, the translator. A study of his theory and his practice as illustrated in his version of the Apologética of St. Gregory Nazianzen. Washington, Catholic University of America.

Watts E. (2012) "Education: Speaking, Thinking and Socializing", in The Oxford Handbook of Late Antiquity. Ed. by F. S. Johnson. Oxford, Oxford University Press.

Wenzel A. (2010) "Libanius, Gregory of Nazianzus, and the Ideal of Athens in Late Antiquity", in Journal of Late Antiquity, vol. 3 (2), pp. 264-285.

Winslow D. F. (1965) "Gregory of Nazianzus and Love for the Poor", in Anglican Theological Review, vol. 47, pp. 348-359.

Winslow D. F. (1979) The Dynamics of Salvation: A Study in Gregory of Nazianzus. Cambridge, Massachusetts, The Philadelphia Patristic Foundation Publ.

Wohlenberg G., Hrsg. (1890) Gregorius' von Nazianz Schutzrede und Chrysostomus' 6 Bücher vom Priestertum: zwei pastoraltheologische Schriften der alten Kirche in einer neuen deutschen Übersetzung. Gotha, Bibliothek theologischer Klassiker Publ.

Zakharov G. E. (2014) "...For there must also be heresies among you": Ecclesiological Problems in the History of Arian Controversie. Moscow, Pravoslavnyi Sviato-Tikhonovskii gumanitarnyi universitet Publ. (In Russian)

Zakharov G. E. (2014) "Constantinople image in St. Gregory Nazianzen writings", in Vestnik universiteta Dmitriia Pozharskogo, vol. 1, pp. 244-251. (In Russian)

Received: February 16, 2021

Accepted: February 26, 2021

Author's information:

Nikolay K. Antonov - Visiting Fellow of Ecclesiastical Institutions Research Laboratory; nickforgo@gmail.com 